\title{
Feasibility of an innovative amorphous silicon photovoltaic/thermal system for medium temperature applications
}

\section{Xiao Ren}

Jing $\mathrm{Li}^{\mathrm{b}}$, *

lijing83@ustc.edu.cn

\section{Mingke $\mathrm{Hu}^{\mathrm{a}}$}

Gang $\mathrm{Pe}^{\mathrm{a}, *}$

peigang@ustc.edu.cn

\section{Dongsheng Jiao ${ }^{a}$}

Xudong Zha

$\mathrm{Jie} \mathrm{Ji}^{\mathrm{a}}$

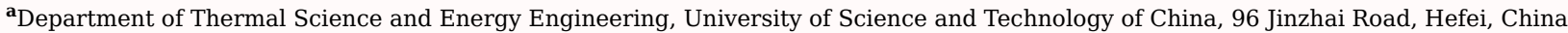

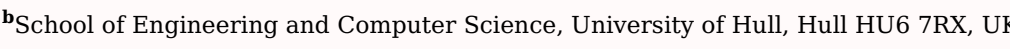

${ }^{*}$ Corresponding authors.

Abstract

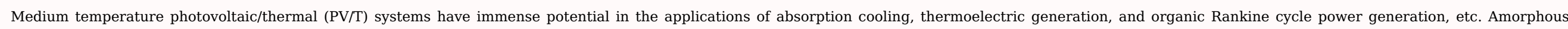

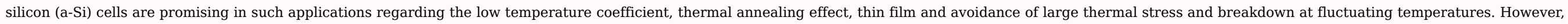

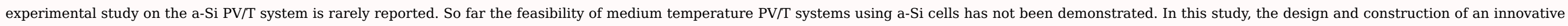

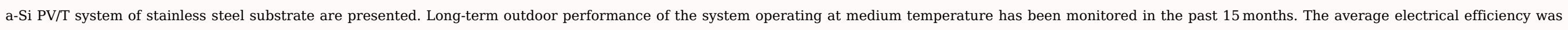

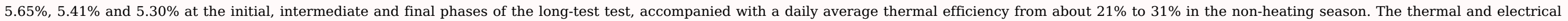

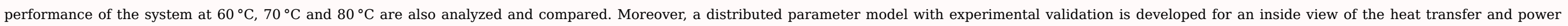

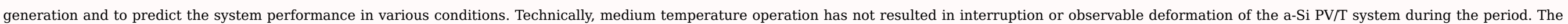
technical and thermodynamic feasibility of the a-Si PV/T system at medium operating temperature is demonstrated by the experimental and simulation results

Keywords: Amorphous silicon cells; Photovoltaic/thermal; Medium temperature; Long-term test; Feasibility

\section{Nomenclature}

area, $\mathrm{m}^{2}$

temperature coefficient, $\mathrm{K}^{-1}$
This work is the accepted manuscript of the article published as https://doi.org/10.1016/.apenergy.2019.113427 and licensed under a Creative Commons Attribution-NonCommercial-NoDerivatives 4.0 International License. 
thickness, $\mathrm{m}$

D

diameter, $\mathrm{m}$

E

electrical gain

G

solar irradiation, $\mathrm{W} / \mathrm{m}^{2}$

heat transfer coefficient, $\mathrm{W} / \mathrm{m}^{2} \mathrm{~K}$

total solar radiation $\mathrm{MJ} / \mathrm{m}^{2} ; \mathrm{J} / \mathrm{m}^{2}$

I

current, A

mass flow rate, $\mathrm{kg} / \mathrm{s}$

$\dot{\mathrm{M}}$

mass flow rate, $\mathrm{kg} / \mathrm{s}$

$\mathrm{Nu}$

Nusselt number, -

perimeter, $\mathrm{m}$

energy, W; kWh

$R$

thermal resistance, $\mathrm{K} / \mathrm{W}$

$R a$

Raleigh number, - 
me, $\mathrm{s}$

temperature, $\mathrm{K}$

$u$

flow velocity, $\mathrm{m} / \mathrm{s}$

$U$

voltage, $\mathrm{V}$

Greek letters

$\alpha$

absorptivity, -

$\beta$

slope angle of collector, ${ }^{\circ}$

incidence angle,

$\phi$

latitude, ${ }^{\circ}$

$\omega$

hour angle of the sun, ${ }^{\circ}$

$\gamma$

surface azimuth angle, ${ }^{\circ}$

$\delta$

declination angle of the sun, ${ }^{\circ}$

$\varepsilon$

emissivity, -

efficiency, -

$(\tau \alpha)_{\mathrm{pv}}$

effective absorption, -

$\xi$

covering factor, -

$\lambda$

thermal conduction, W/m K 


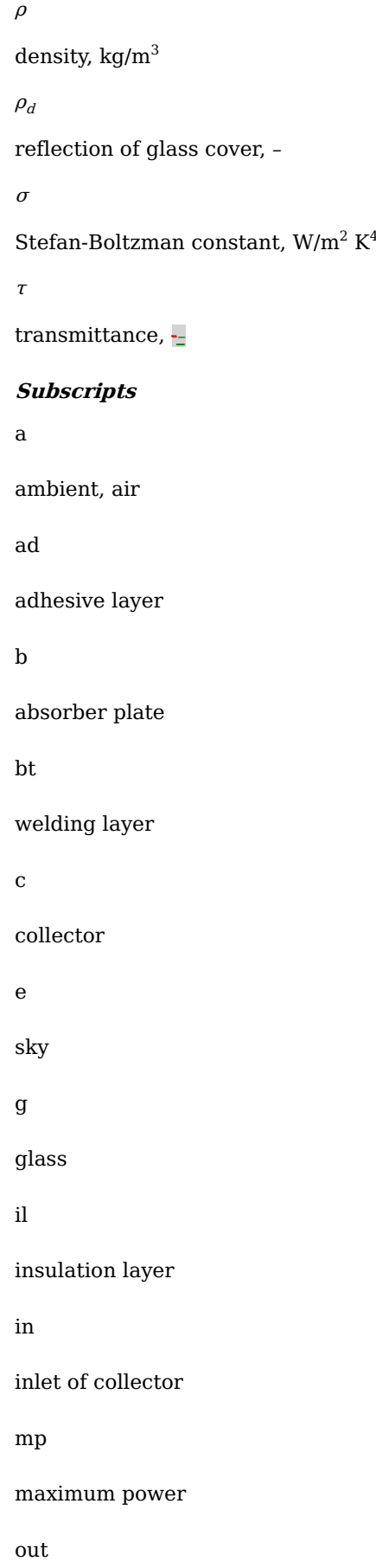




\section{Introduction}

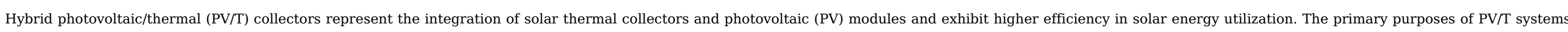

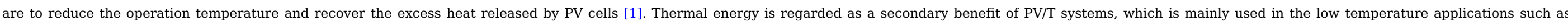
domestic hot water and space heating.

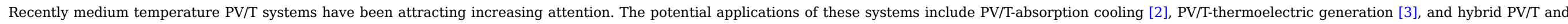

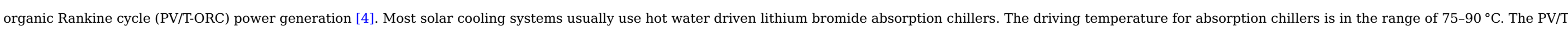

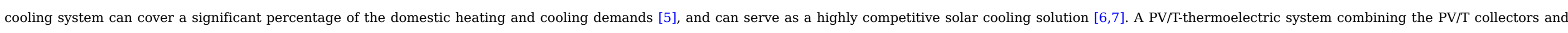

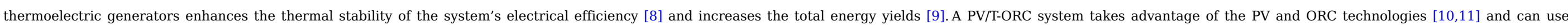
thermal storage e.g. water instead of battery for flexible power generation [12,13].

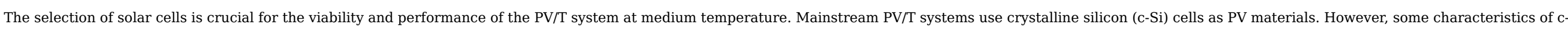

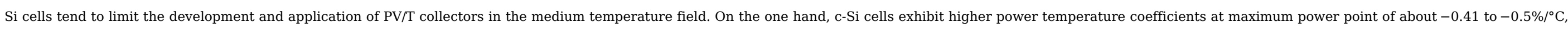

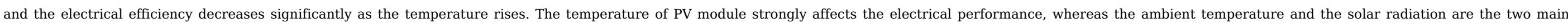

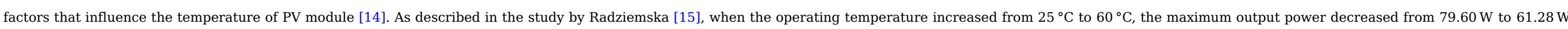

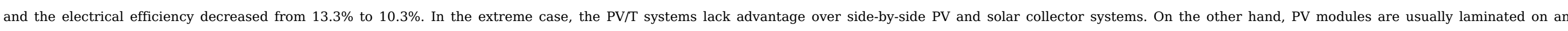

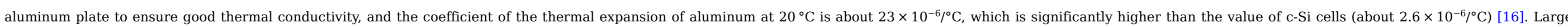

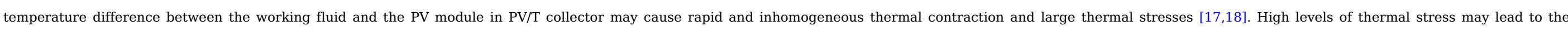

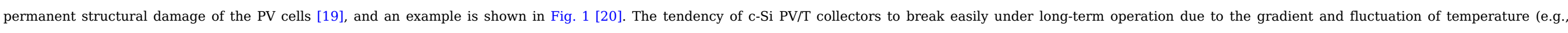

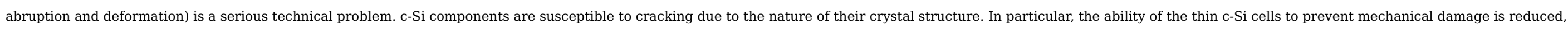
and micro-cracks are more prone to occur [21]. 


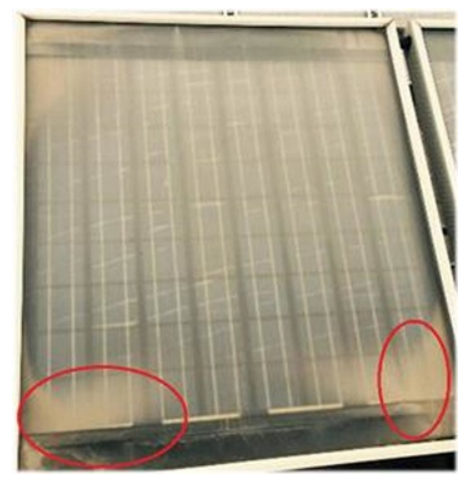

Fig. 1 A broken c-Si PV/T collector.

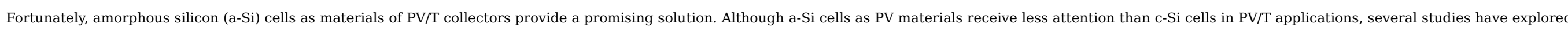

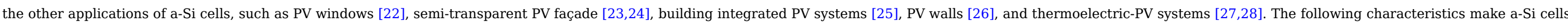
highly suitable for operating at medium temperature.

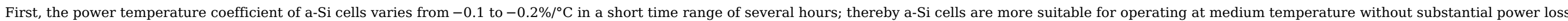
[29]. Studies have also shown that the power temperature coefficients of a-Si cells exhibited positive in a long time test [30,31].

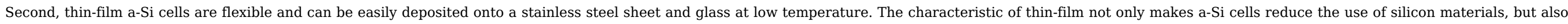
presents lower thermal resistance than c-Si cells. Moreover, a-Si cells can avoid huge thermal stress and overcome the problem of interruptions at fluctuating temperatures in PV/T collectors.

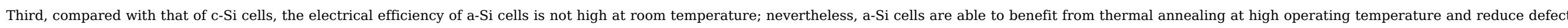

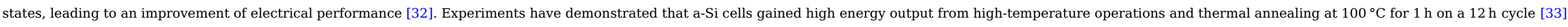

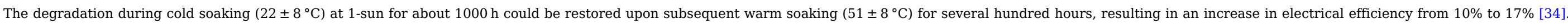
Therefore, a-Si cells are expected to exhibit high electrical efficiency at high temperatures.

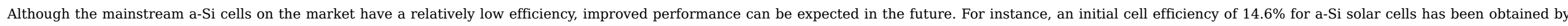

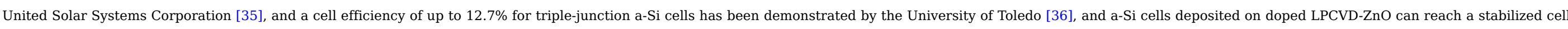
efficiency of $10.09 \%$ [37]. The above characteristics suggest that a-Si cells are a promising choice as PV materials for PV/T collectors used in the fields of medium temperature.

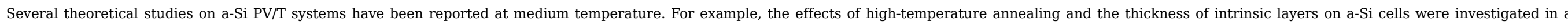

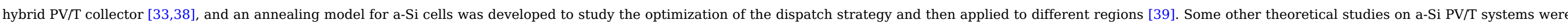

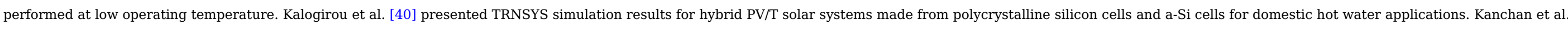

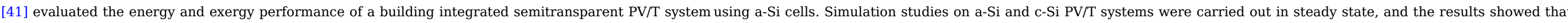

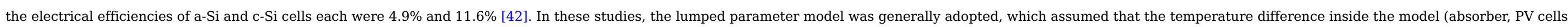

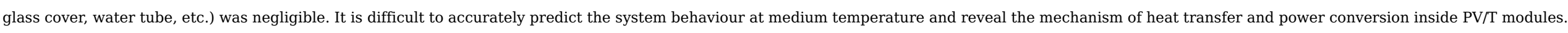

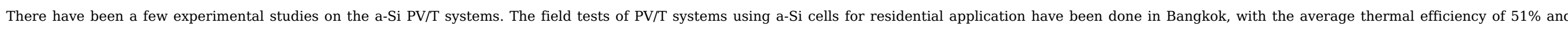

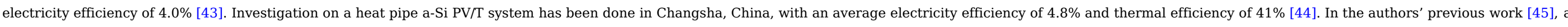

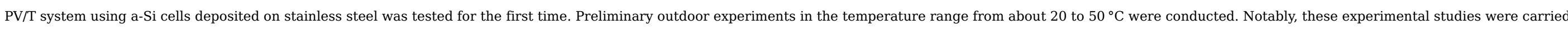
out at low operating temperature. Medium temperature experiment on a-Si PV/T system is rarely reported.

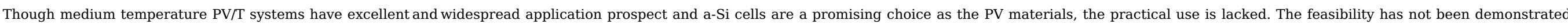




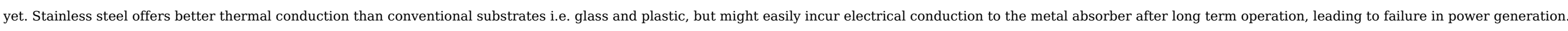
The lifetime of the a-Si PV/T system in the medium temperature application is unknown. Both the technical and thermodynamic issues need to be clarified.

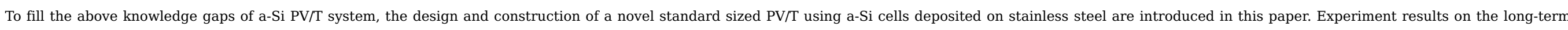

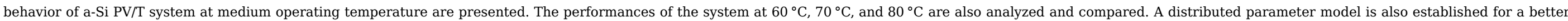
understanding of the heat transfer and power generation and to analyze the system behavior in both heating and non-heating period. Finally, the technical and thermodynamic feasibility is demonstrated.

\section{Description of the a-Si PV/T system and experimental setup}

\subsection{Description of the a-Si PV/T collector}

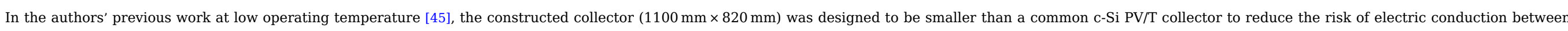
the stainless steel and aluminum absorber. The thermal performance of the first prototype was expected to be low due to its small size.

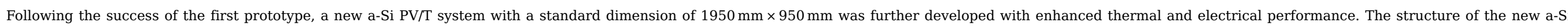

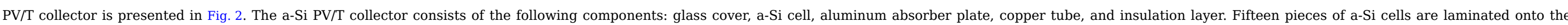

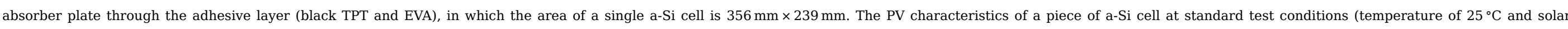

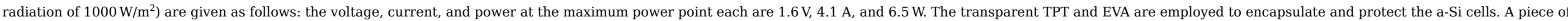

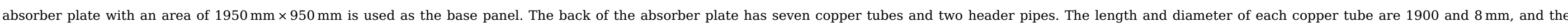

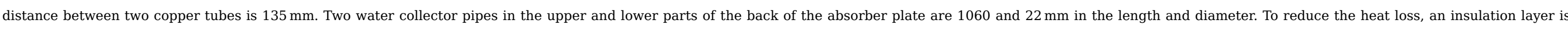
employed on the bottom of the a-Si PV/T collector.

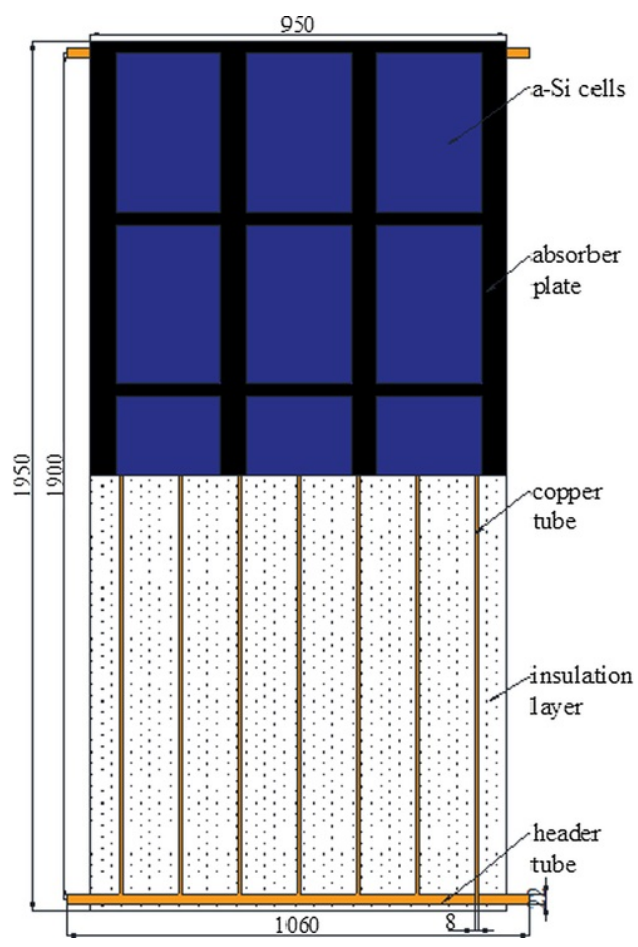

Fig. 2 Structure and dimensions of the a-Si PV/T collector 


\subsection{Experimental setup}

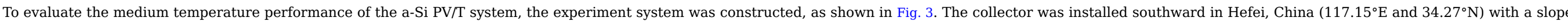

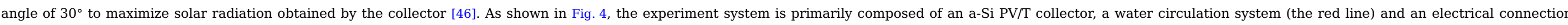

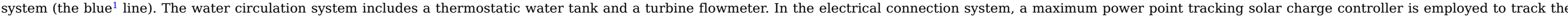

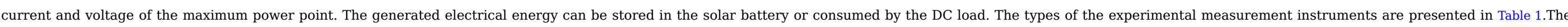

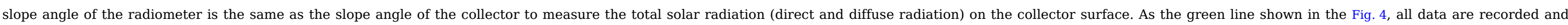
stored by the Agilent Bench Link Data Logger (34980A) with a time internal of $10 \mathrm{~s}$.

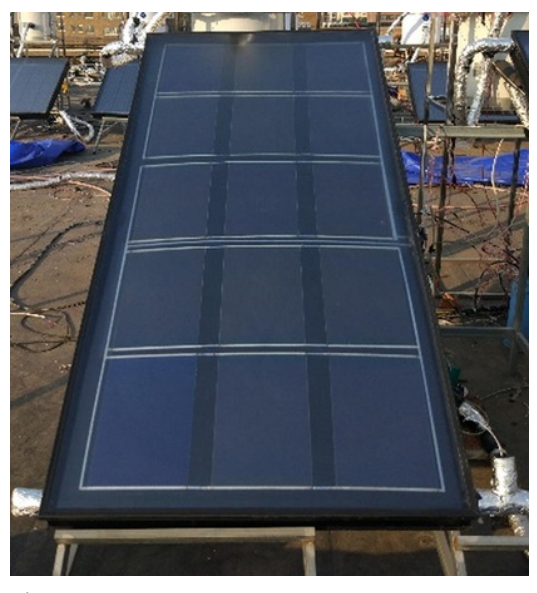

Fig. 3 Actual setup of the a-Si PV/T system test rig. 


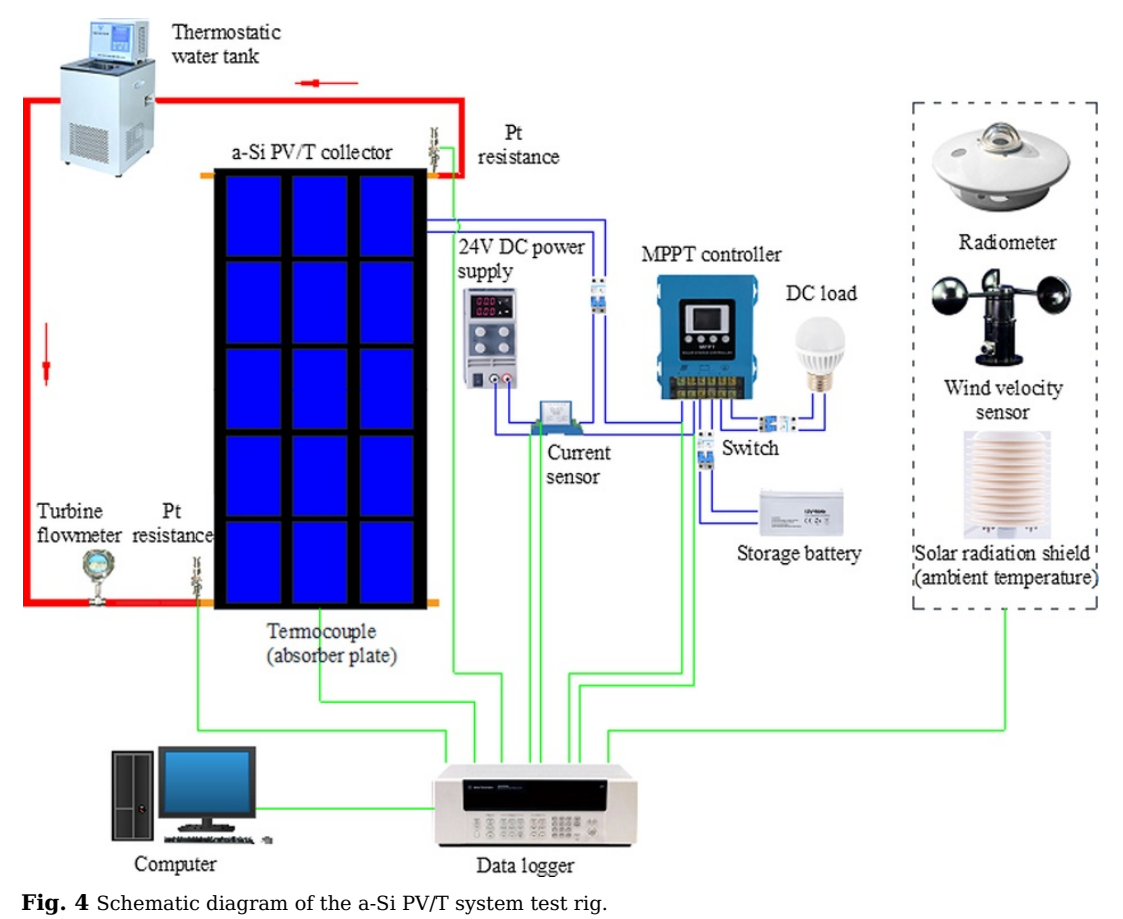

Fig. 4 Schematic diagram of the a-Si PV/T system test rig.

Table 1 Types of experimental measurement instruments.

\begin{tabular}{|c|c|c|c|}
\hline Instruments & Types & Uncertainty & Location \\
\hline Platinum resistance & Pt 100 & $\pm 0.1^{\circ} \mathrm{C}$ & Inlet and outlet of collector \\
\hline Thermocouple & Type T & $\pm 0.5^{\circ} \mathrm{C}$ & Ambient; absorber plate \\
\hline Flowmeter & LWGY & $\pm 5 \%$ & Outlet of the thermostatic water tank \\
\hline Current sensor & HKK-13-I & $\pm 0.1 \%$ & PV module output circuit \\
\hline Radiometer & TBQ-2 & $\pm 2 \%$ & Solar collector \\
\hline
\end{tabular}

\section{Mathematical model and simulation}

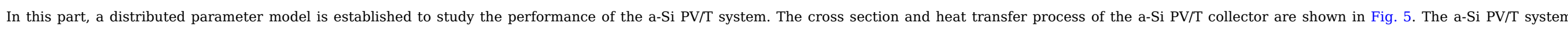

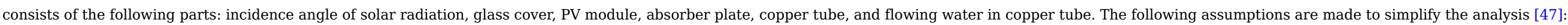

(1) The water flow rate in each copper tube is uniform. Hence, the temperature of the absorber plate is assumed to be symmetrically distributed along the axial direction of each copper tube.

(2) The temperature gradients of the glass cover, PV module, absorber plate, and copper pipe along the thickness direction are negligible. 


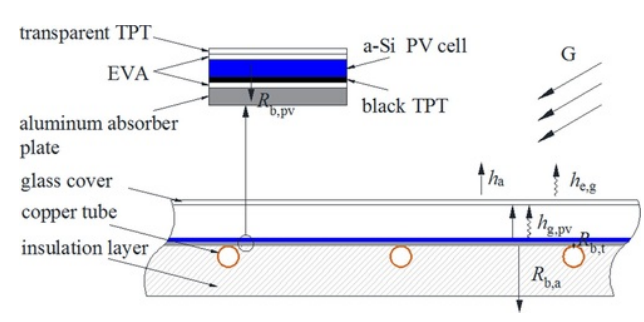

Fig. 5 Cross section and heat transfer process of the a-Si PV/T collector.

\subsection{Modeling of the incidence angle of solar radiation on the collector surface}

The angle of incidence of solar radiation on the collector surface is defined as [48]

$\cos \theta=\sin \delta(\sin \phi \cos \beta-\cos \phi \sin \beta \cos \gamma)+\cos \delta \cos \omega \cos \phi \cos \beta$

$+\cos \delta \cos \omega \sin \phi \sin \beta \cos \gamma+\cos \delta \sin \beta \sin \gamma \sin \omega$

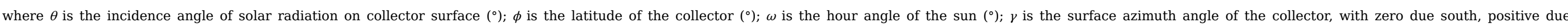
west, and negative due east $\left(^{\circ}\right)$; and $\delta$ is the declination angle of the sun $\left(^{\circ}\right)$.

The PV/T collector is facing south, and thus, the incidence angle can be simplified as

$\cos \theta=\sin \delta \sin (\phi-\beta)+\cos \delta \cos \omega \cos (\phi-\beta)$

\subsection{Modeling of glass cover}

The energy balance equation of the glass cover can be expressed as

$$
\rho_{\mathrm{g}} c_{\mathrm{g}} d_{\mathrm{g}} \frac{\partial T_{\mathrm{g}}}{\partial t}=h_{\mathrm{a}}\left(T_{\mathrm{a}}-T_{\mathrm{g}}\right)+h_{\mathrm{e}, \mathrm{g}}\left(T_{\mathrm{e}}-T_{\mathrm{g}}\right)+h_{\mathrm{g}, \mathrm{pv}}\left(T_{\mathrm{pv}}-T_{\mathrm{g}}\right)+G \alpha_{\mathrm{g}}
$$

where $h_{\mathrm{e}, \mathrm{g}}$ is the radiant heat transfer coefficient between the glass cover and sky; $h_{\mathrm{g}, \mathrm{pv}}$ is the heat transfer coefficient between the glass cover and a-Si cells combines convection and radiation, expressed as

$$
\begin{aligned}
h_{\mathrm{g}, \mathrm{pv}}=\sigma\left(T_{\mathrm{pv}}^{2}+T_{\mathrm{g}}^{2}\right)\left(T_{\mathrm{pv}}+T_{\mathrm{g}}\right) & \left.\frac{\xi}{1 / \varepsilon_{\mathrm{pv}} \xi_{\left(1 / \varepsilon_{\mathrm{g}}-1\right)}}+\frac{1-\xi}{1 / \varepsilon_{\mathrm{pv}}+(1-\xi)\left(1 / \varepsilon_{\mathrm{g}}-1\right)}\right) \\
+ & \frac{N u \cdot \lambda_{\mathrm{a}}}{d_{\mathrm{a}}}
\end{aligned}
$$

where $\xi$ is the covering factor of PV cells and is defined as

$$
\xi=A_{\mathrm{pv}} / A_{\mathrm{c}}
$$

For the tilt angle of the collector within $0^{\circ}$ to $75^{\circ}$, the Nusselt number is expressed as [49]

$$
N u=1+1.14\left(1-\frac{1708(\sin 1.8 \beta)^{1.6}}{R a \cdot \cos \beta}\right)\left[1-\frac{1708}{R a \cdot \cos \beta}\right]^{+}+\left[\left(\frac{R a \cdot \cos \beta}{5830}\right)^{1 / 3}-1\right]^{+}
$$

where []$^{+}$indicates that only positive values for the terms in the square brackets are used; in case of negative values, zero is used.

\subsection{Modeling of PV module}

The two-dimensional energy balance equation for the PV module is expressed as

$$
\begin{gathered}
\rho_{\mathrm{pv}} c_{\mathrm{pv}} d_{\mathrm{pv}} \frac{\partial T_{\mathrm{pv}}}{\partial t}=\lambda_{\mathrm{pv}} d_{\mathrm{pv}}\left(\frac{\partial^{2} T_{\mathrm{pv}}}{\partial x^{2}}+\frac{\partial^{2} T_{\mathrm{pv}}}{\partial y^{2}}\right)+h_{\mathrm{g}, \mathrm{pv}}\left(T_{\mathrm{g}}-T_{\mathrm{pv}}\right)+\left(T_{\mathrm{b}}-T_{\mathrm{pv}}\right) / R_{\mathrm{b}, \mathrm{pv}} \\
+G(\tau \alpha)_{\mathrm{pv}}-\xi E_{\mathrm{pv}}
\end{gathered}
$$

The effective absorption $(\tau \alpha)_{\mathrm{pv}}$ and output power $E_{\mathrm{pv}}$ of the PV module are respectively expressed as 
$(\tau \alpha)_{\mathrm{pv}}=\frac{\tau_{\mathrm{g}} \tau_{\mathrm{ad}} \alpha}{1-(1-\alpha) \rho_{\mathrm{d}}}$

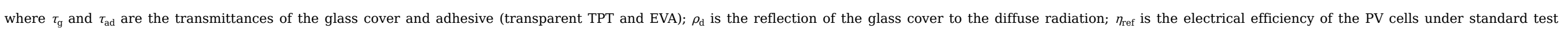

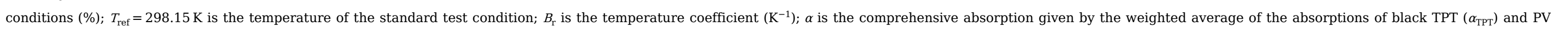
cells $\left(\alpha_{\mathrm{pv}}\right)$ and expressed as

$$
\alpha=\xi \alpha_{\mathrm{pv}}+(1-\xi) \alpha_{\mathrm{TPT}}
$$

$R_{\mathrm{b}, \mathrm{pv}}$ is the thermal resistance of the adhesive layer (black TPT and EVA) between the absorber plate and PV module $\left(\mathrm{m}^{2} \mathrm{~K} / \mathrm{W}\right)$ and is expressed as

$R_{\mathrm{b}, \mathrm{pv}}=\frac{d_{\mathrm{ad}}}{\lambda_{\mathrm{ad}}}$

\subsection{Modeling of absorber plate}

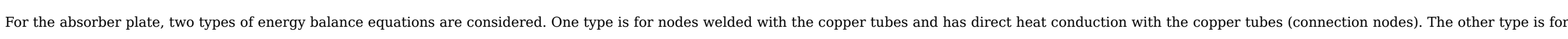
the part between the copper tubes (middle nodes).

The energy balance equation of the connection nodes is given as

$$
\rho_{\mathrm{b}} c_{\mathrm{b}} d_{\mathrm{b}} \frac{\partial T_{\mathrm{b}}}{\partial t}=\lambda_{\mathrm{b}} d_{\mathrm{b}}\left(\frac{\partial^{2} T_{\mathrm{b}}}{\partial x^{2}}+\frac{\partial^{2} T_{\mathrm{b}}}{\partial y^{2}}\right)+\left(T_{\mathrm{pv}}-T_{\mathrm{b}}\right) / R_{\mathrm{b}, \mathrm{pv}}+\frac{T_{\mathrm{t}}-T_{\mathrm{b}}}{R_{\mathrm{b}, \mathrm{t}} \cdot A_{i j}}
$$

The energy balance equation of the middle nodes is given as

$$
\rho_{\mathrm{b}} c_{\mathrm{b}} d_{\mathrm{b}} \frac{\partial T_{\mathrm{b}}}{\partial t}=\lambda_{\mathrm{b}} d_{\mathrm{b}}\left(\frac{\partial^{2} T_{\mathrm{b}}}{\partial x^{2}}+\frac{\partial^{2} T_{\mathrm{b}}}{\partial y^{2}}\right)+\left(T_{\mathrm{pv}}-T_{\mathrm{b}}\right) / R_{\mathrm{b}, \mathrm{pv}}+\left(T_{\mathrm{a}}-T_{\mathrm{b}}\right) / R_{\mathrm{b}, \mathrm{a}}
$$

where $A_{i j}$ is the area of a single controller $\left(\mathrm{m}^{2}\right)$.

The thermal resistance $R_{\mathrm{b}, \mathrm{a}}\left(\mathrm{m}^{2} \cdot \mathrm{K} / \mathrm{W}\right)$ between the absorber plate and ambient air is written as $R_{\mathrm{b}, \mathrm{a}}=d_{\mathrm{il}} / \lambda_{\mathrm{il}}+1 / h_{\mathrm{a}}$

The thermal resistance $R_{\mathrm{b}, \mathrm{t}}(\mathrm{K} / \mathrm{W})$ between the absorber plate and copper pipe is expressed as $R_{\mathrm{b}, \mathrm{t}}=d_{\mathrm{bt}} /\left(\lambda_{\mathrm{bt}} \cdot A_{\mathrm{bt}}\right)$

where $A_{\mathrm{bt}}$ is the welding area in a single controller $\left(\mathrm{m}^{2}\right)$.

\subsection{Modeling of copper tube}

The energy balance equation of the copper tube is expressed as

$$
A_{\mathrm{t}} \rho_{\mathrm{t}} c_{\mathrm{t}} \frac{\partial T_{\mathrm{t}}}{\partial t}=A_{\mathrm{t}} \lambda_{\mathrm{t}} \frac{\partial^{2} T_{\mathrm{t}}}{\partial x^{2}}+\pi D_{\mathrm{t}} h_{\mathrm{w}, \mathrm{t}}\left(T_{\mathrm{w}}-T_{\mathrm{t}}\right)+\frac{T_{\mathrm{b}}-T_{\mathrm{t}}}{R_{\mathrm{b}, \mathrm{t}} \cdot d x}
$$

where $h_{\mathrm{w}, \mathrm{t}}$ is the convective heat transfer coefficient between the copper tube and water flow $\left(\mathrm{W} /\left(\mathrm{m}^{2} \mathrm{~K}\right)\right)$.

\subsection{Modeling of water flow}

For the water flowing in the copper tube, the energy balance equation is expressed as

$$
A_{\mathrm{w}} \rho_{\mathrm{w}} c_{\mathrm{w}} \frac{\partial T_{\mathrm{w}}}{\partial t}=-\dot{m} c_{\mathrm{w}} \frac{\partial T_{\mathrm{w}}}{\partial x}+A_{\mathrm{w}} \lambda_{\mathrm{w}} \frac{\partial^{2} T_{\mathrm{w}}}{\partial x^{2}}+P_{\mathrm{w}} h_{\mathrm{w}, \mathrm{t}}\left(T_{\mathrm{t}}-T_{\mathrm{w}}\right)
$$


where $\mathrm{m}$ is the mass flowing rate of the water in a single copper tube $(\mathrm{kg} / \mathrm{s}) ; A_{\mathrm{t}}$ and $P_{\mathrm{t}}$ are the cross-sectional area $\left(\mathrm{m}^{2}\right)$ and perimeter of the runner in the copper tube (m).

\subsection{Performance evaluation}

The instantaneous thermal efficiency of the collector can be defined as

$\eta_{\text {th }}=\frac{\dot{M} c_{\mathrm{w}}\left(T_{\text {out }}-T_{\text {in }}\right)}{G A_{\mathrm{c}}}$

where $\dot{M}$ is the mass flowing rate of the water in collector $(\mathrm{kg} / \mathrm{s}) ; T_{\mathrm{out}}$ and $T_{\mathrm{in}}$ are the outlet and inlet temperatures of the collector $(\mathrm{K})$

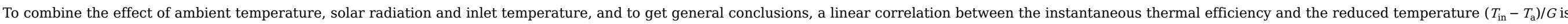
built, expressed as [50]:

$\eta_{\text {th }}=F_{\mathrm{R}}(\tau \alpha)_{\mathrm{e}}-F_{\mathrm{R}} U_{\mathrm{L}} \frac{T_{\text {in }}-T_{\mathrm{a}}}{G}$

The intercept $F_{\mathrm{R}}(\tau \alpha)_{\mathrm{e}}$ and slope $F_{\mathrm{R}} U_{\mathrm{L}}$ are the thermal efficiency at zero reduced temperature and the heat loss of the collector.

The electrical efficiency is defined as ratio of the electrical power to the incident solar radiation

$\eta_{\mathrm{pv}}=\frac{E_{\mathrm{pv}}}{G A_{\mathrm{pv}}}$

For the simulation, the electrical power is calculated by Eq.(9), while the experimental electrical power is expressed as

$E_{\mathrm{pv}}=U_{\mathrm{mp}} I_{\mathrm{mp}}$

To evaluate the degree of agreement between the simulation and the experimental results, mean relative error (MRE) is defined as

MRE $=\frac{\sum_{i=1}^{i=N}\left|X_{\exp }-X_{\text {sim }}\right|}{\sum_{i=1}^{i=N} X_{\text {exp }}} \times 100 \%$

where $X_{\exp }$ and $X_{\text {sim }}$ are the experimental and simulation results, respectively.

\section{Discretization of equations and numerical simulation}

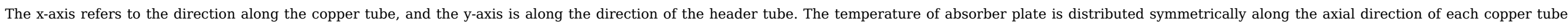

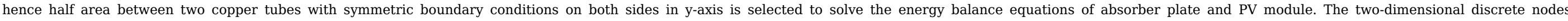
$(i \times j=51 \times 11)$ of the PV module and absorber plate are shown in the Fig. 6 . For the copper tube and the water in it, $49 \times 1$ nodes are established for grid discretization.

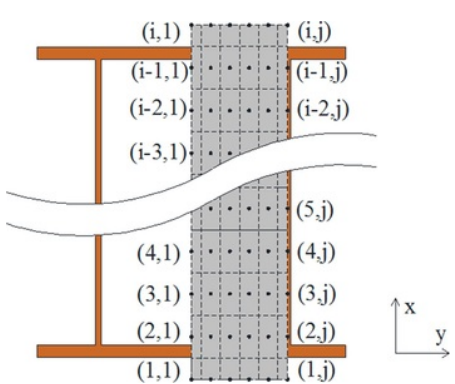

Fig. 6 Differential grid partition of PV module and absorber plate.

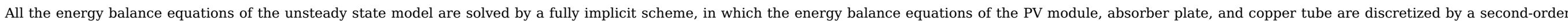


For the glass cover:

$\rho_{\mathrm{g}} c_{\mathrm{g}} d_{\mathrm{g}}\left(T_{\mathrm{g}}^{1}-T_{\mathrm{g}}^{0}\right)=h_{\mathrm{a}}\left(T_{\mathrm{a}}-T_{\mathrm{g}}^{1}\right)+h_{\mathrm{e}, \mathrm{g}}\left(T_{\mathrm{e}}-T_{\mathrm{g}}^{1}\right)+h_{\mathrm{g}, \mathrm{pv}}\left(T_{\mathrm{pv}}^{1}-T_{\mathrm{g}}^{1}\right)+G \alpha_{\mathrm{g}}$

For the PV module:

$\rho_{\mathrm{pv}} c_{\mathrm{pv}} d_{\mathrm{pv}} \frac{T_{\mathrm{pv}(i, j)}^{1}-T_{\mathrm{pv}(i, j)}^{0}}{\Delta t}=\lambda_{\mathrm{pv}} d_{\mathrm{pv}} \frac{T_{\mathrm{pv}(i+1, j)}^{1}-2 T_{\mathrm{pv}(i, j)}^{1}+T_{\mathrm{pv}(i-1, j)}^{1}}{\Delta x^{2}}$
$+\lambda_{\mathrm{pv}} d_{\mathrm{pv}} \frac{\left.T_{\mathrm{pv}(i, j+1)}^{1}-2 T_{\mathrm{pv}(i, j)}^{1}\right) T_{\mathrm{pv}(i, j-1)}^{1}}{\Delta y^{2}}$
$+h_{\mathrm{g}, \mathrm{pv}}\left(T_{\mathrm{g}}^{1}-T_{\mathrm{pv}(i, j)}^{1}\right)+\frac{T_{\mathrm{b}(i, j)}^{1} T_{\mathrm{pv}(i, j)}^{1}}{R_{\mathrm{b}, \mathrm{pv}}}+G(\tau \alpha)_{\mathrm{pv}}-\xi E_{\mathrm{pv}}$

For the middle nodes of the absorber plate:

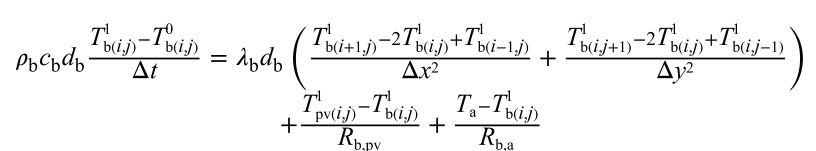

For the connection nodes of the absorber plate:

$$
\begin{aligned}
\rho_{\mathrm{b}} c_{\mathrm{b}} d_{\mathrm{b}} \frac{T_{\mathrm{b}(i, 11)}^{1}-T_{\mathrm{b}(i, 11)}^{0}}{\Delta t} & =\lambda_{\mathrm{b}} d_{\mathrm{b}}\left(\frac{T_{\mathrm{b}(i+1,1,1)}^{1}-2 T_{\mathrm{b}(i, 11)}^{1}+T_{\mathrm{b}(i-1,1,1)}^{1}}{\Delta x^{2}}+2 \frac{T_{\mathrm{b}(i, 10)}^{1}-T_{\mathrm{b}(i, 11)}^{1}}{\Delta y^{2}}\right) \\
& +\frac{T_{\mathrm{pv}(i, 1)}^{1}-T_{\mathrm{b}(i, 11)}^{1}}{R_{\mathrm{b}, \mathrm{pv}}}+\frac{T_{\mathrm{t}(i-1,1)}^{1}-T_{\mathrm{b}(i, 11)}^{1}}{R_{\mathrm{b}, \mathrm{t}} \cdot A_{\mathrm{ij}}}
\end{aligned}
$$

For the copper tube:

$$
\begin{aligned}
& A_{t} \rho_{\mathrm{t}} c_{\mathrm{t}} \frac{T_{\mathrm{t}(i, 1)}^{1}-T_{\mathrm{t}(i, 1)}^{0}}{\Delta t}=A_{t} \lambda_{t} \frac{T_{\mathrm{t}(i+1,1)}^{1}-2 T_{\mathrm{t}(i, 1)}^{1}+T_{\mathrm{t}(i-1,1)}^{1}}{\Delta x^{2}} \\
& \quad+\pi D_{\mathrm{t}} h_{\mathrm{w}, \mathrm{t}}\left(T_{\mathrm{w}(i, 1)}^{1}-T_{\mathrm{t}(i, 1)}^{1}\right)+\frac{T_{\mathrm{b}(i+1,1,1)}^{1}-T_{\mathrm{t}(i, 1)}^{1}}{R_{\mathrm{b}, \mathrm{t}}-\Delta x}
\end{aligned}
$$

For the water in the copper tube:

$$
\begin{gathered}
A_{\mathrm{w}} \rho_{\mathrm{w}} c_{\mathrm{w}} \frac{T_{\mathrm{w}(i, 1)}^{\mathrm{1}}-T_{\mathrm{w}(i, 1)}^{0}}{\Delta t}=-\dot{m} c_{\mathrm{w}} \frac{T_{\mathrm{w}(i-2,1)}^{\mathrm{1}}-4 T_{\mathrm{w}(i-1,1)}^{1}+3 T_{\mathrm{w}(i, 1)}^{1}}{2 \Delta x} \\
+A_{\mathrm{w}} \lambda_{\mathrm{w}} \frac{T_{\mathrm{w}(i+1,1)}^{1}-2 T_{\mathrm{w}(i, 1)}^{1}+T_{\mathrm{w}(i-1,1)}^{1}}{\Delta x^{2}}+P_{\mathrm{w}} h_{\mathrm{w}, \mathrm{t}}\left(T_{\mathrm{t}(i, 1)}^{1}-T_{\mathrm{w}(i, 1)}^{1}\right)
\end{gathered}
$$

In these equations, the superscript " 0 " represents the results of the previous time and " 1 " refers to the results of the current time.

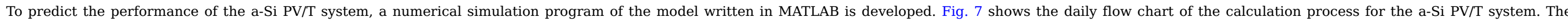

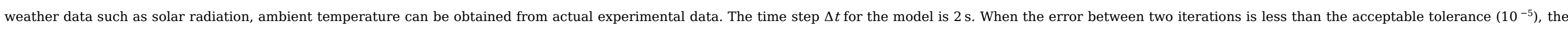
system is considered to reach the steady-state and then moves to next time. 


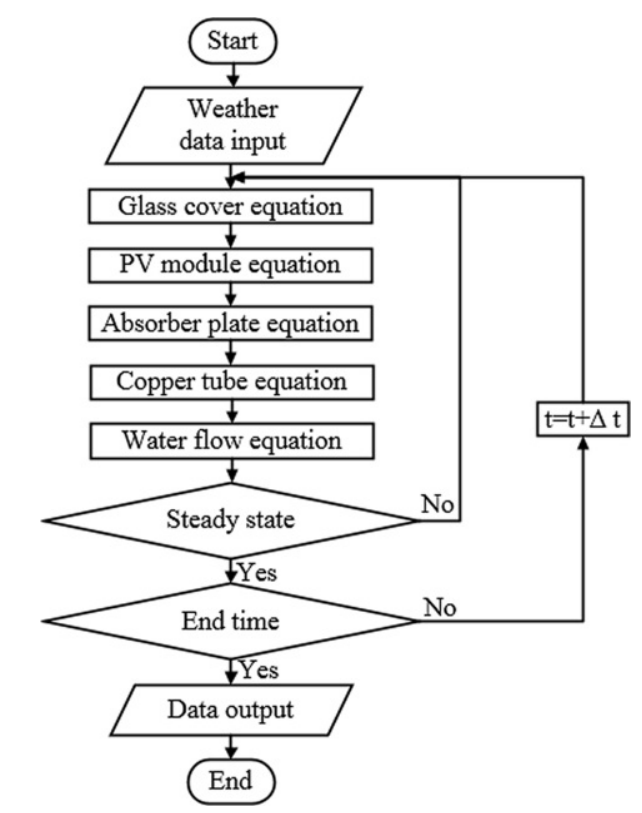

Fig. 7 Daily flow chart of the calculation process for the a-Si PV/T system.

\section{Results and discussion}

\subsection{Experimental results at medium operating temperature}

\subsubsection{Long-term experimental results at the operating temperature of $60^{\circ} \mathrm{C}$}

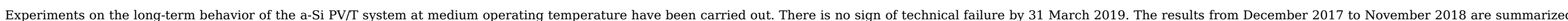

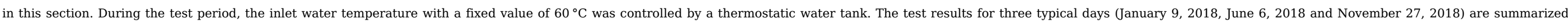

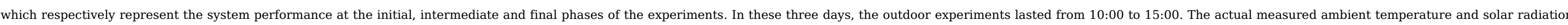
are shown in Fig. 8. During the test, the daily average ambient temperatures were $5.3{ }^{\circ} \mathrm{C}, 26.3{ }^{\circ} \mathrm{C}$ and $21.0^{\circ} \mathrm{C}$; the total solar radiations each were $15.17 \mathrm{MJ} / \mathrm{m}^{2}, 16.35 \mathrm{MJ} / \mathrm{m}^{2}$ and $12.64 \mathrm{MJ} / \mathrm{m}^{2}$. 

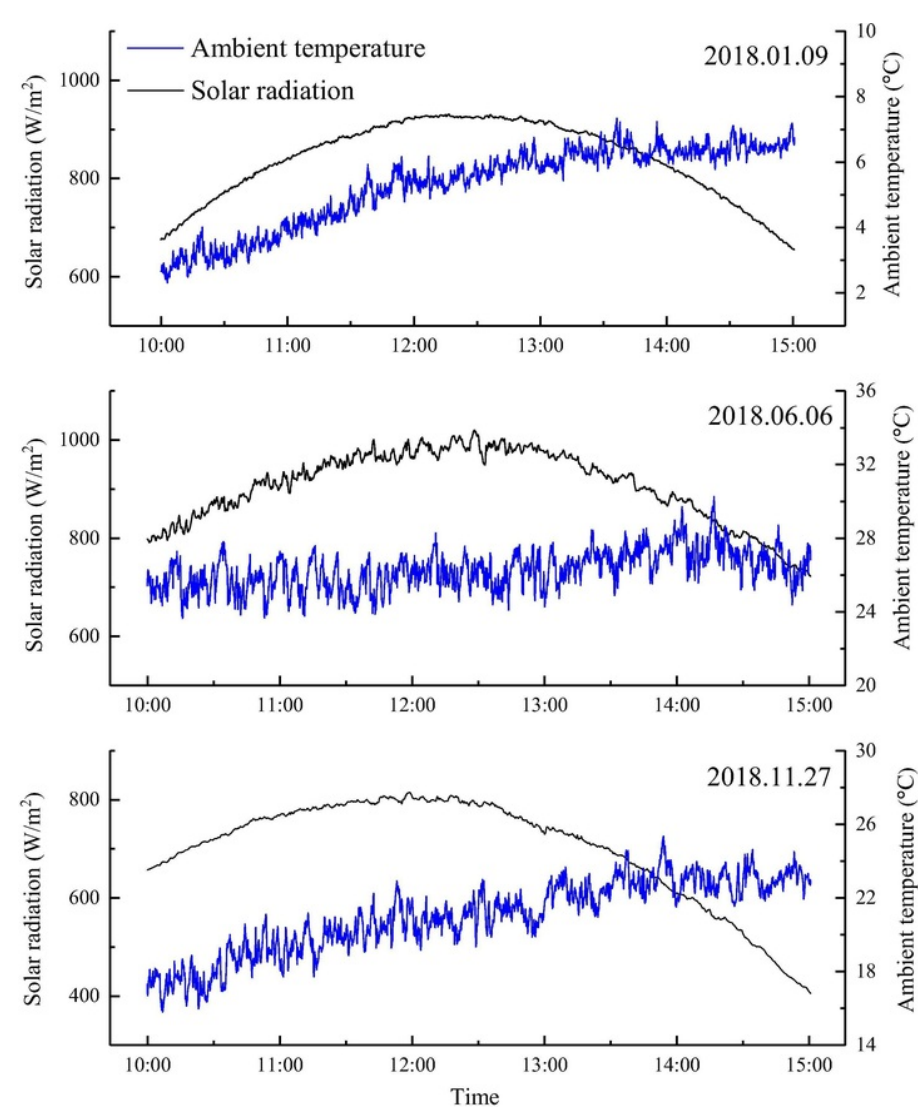

Fig. 8 Variations of ambient temperature and solar radiation.

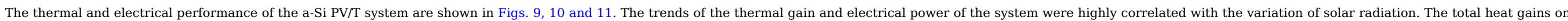

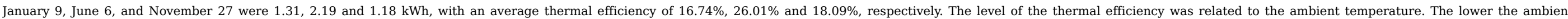

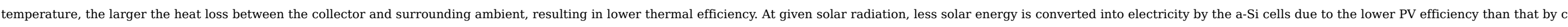

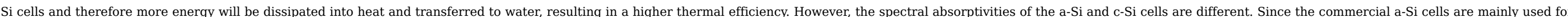

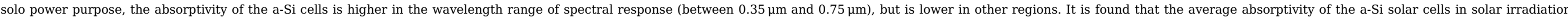

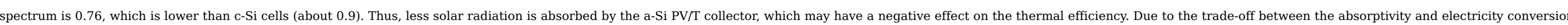
efficiency, the thermal efficiency of the a-Si PV/T collector might be lower than that of common c-Si PV/T collectors at the same conditions of operating temperature and solar radiation. 

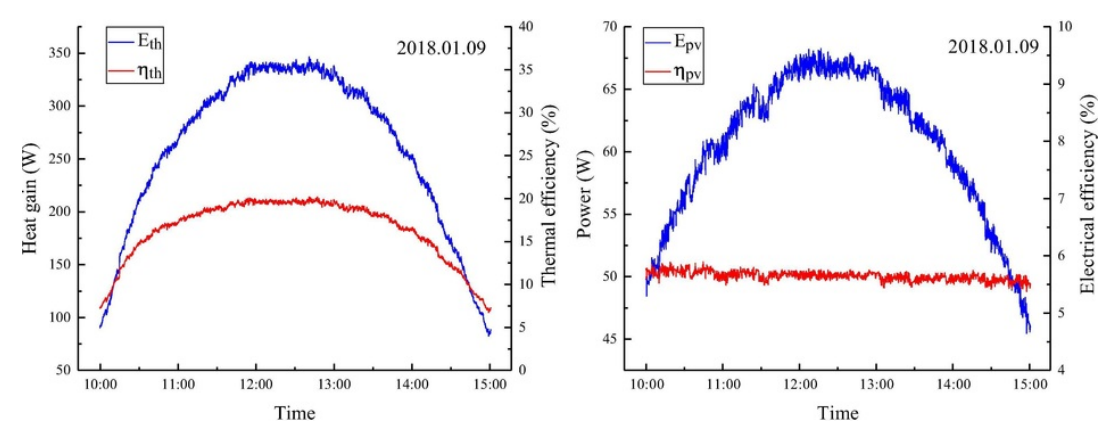

Fig. 9 Variations of thermal and electrical performance on January 9, 2018.
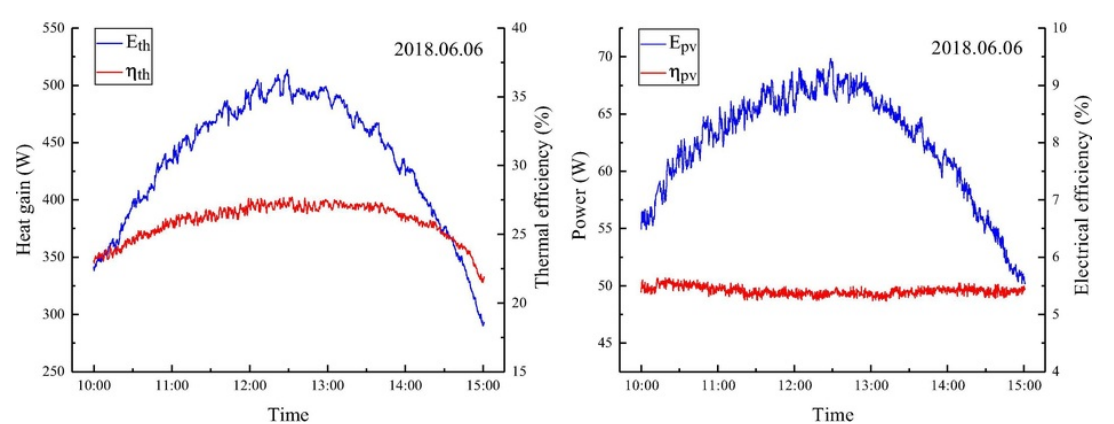

Fig. 10 Variations of thermal and electrical performance on June 6, 2018.

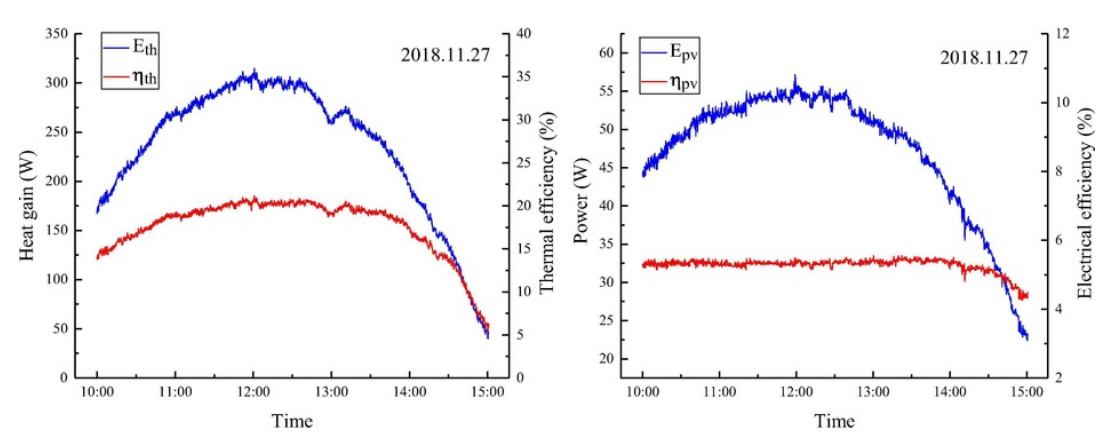

Fig. 11 Variations of thermal and electrical performance on November 27, 2018.

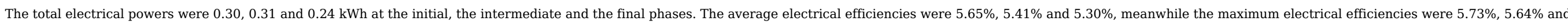
$5.55 \%$. There was a significant drop in electrical efficiency due to the Staebler-Wronski (S-W) effect [51]. The S-W effect is related with the light-induced degradation of electrical performance and the creation of defect states.

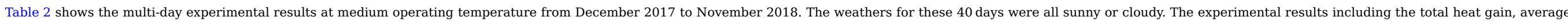

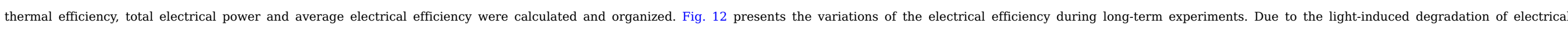

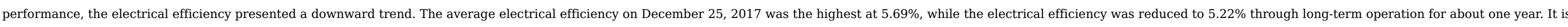

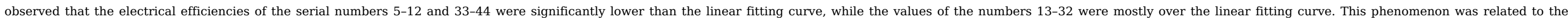
seasonal variation of a-Si cells. Due to the S-W effect and spectral effect, a-Si cells exhibited higher electrical efficiency in summer but lower electrical efficiency in winter, which was different from c-Si cells [52,53].

Table 2 Multi-day experimental results of a-Si PV/T system at medium operating temperature. 


\begin{tabular}{|c|c|c|c|c|c|c|c|c|}
\hline Number & Date & $\overline{\mathrm{T}_{\mathrm{a}}}(\circ \mathrm{C})$ & $\mathrm{m}^{(\mathrm{kg} / \mathrm{s})}$ & $\mathrm{H}\left(\mathrm{MJ} / \mathrm{m}^{2}\right)$ & $\mathrm{Q}_{\mathrm{th}}(\mathrm{kWh})$ & $\eta_{\mathrm{th}, \mathrm{a}}(\%)$ & $\mathrm{Q}_{\mathrm{pv}}(\mathrm{kWh})$ & $\eta_{\mathrm{pv}, \mathrm{a}}(\%)$ \\
\hline 1 & 12.25 & 10.2 & 0.036 & 12.80 & 1.09 & 16.47 & 0.26 & 5.69 \\
\hline 2 & 12.26 & 12.5 & 0.036 & 11.37 & 0.90 & 15.38 & 0.22 & 5.62 \\
\hline 3 & 1.09 & 5.3 & 0.036 & 15.17 & 1.31 & 16.74 & 0.30 & 5.65 \\
\hline 4 & 1.10 & 4.1 & 0.044 & 14.49 & 1.27 & 17.08 & 0.29 & 5.64 \\
\hline 5 & 1.11 & 3.9 & 0.028 & 13.92 & 1.05 & 14.69 & 0.27 & 5.57 \\
\hline 6 & 1.12 & 2.6 & 0.036 & 14.48 & 1.12 & 15.08 & 0.28 & 5.52 \\
\hline 7 & 3.09 & 11.9 & 0.028 & 15.41 & 1.60 & 20.15 & 0.30 & 5.47 \\
\hline 8 & 3.10 & 16.7 & 0.026 & 16.60 & 1.85 & 21.63 & 0.32 & 5.41 \\
\hline 9 & 3.11 & 19.3 & 0.028 & 16.56 & 1.97 & 23.12 & 0.32 & 5.44 \\
\hline 10 & 3.12 & 22.0 & 0.026 & 16.17 & 2.16 & 25.93 & 0.31 & 5.46 \\
\hline 11 & 3.13 & 23.6 & 0.042 & 15.79 & 2.50 & 30.77 & 0.31 & 5.50 \\
\hline 12 & 3.23 & 19.7 & 0.042 & 16.23 & 2.54 & 30.36 & 0.31 & 5.40 \\
\hline 13 & 3.26 & 22.6 & 0.043 & 14.27 & 2.29 & 31.16 & 0.28 & 5.52 \\
\hline 14 & 3.27 & 22.88 & 0.031 & 15.08 & 2.21 & 28.45 & 0.30 & 5.54 \\
\hline 15 & 3.31 & 26.0 & 0.031 & 14.67 & 2.25 & 29.85 & 0.29 & 5.62 \\
\hline 16 & 4.02 & 28.5 & 0.031 & 14.09 & 2.14 & 29.54 & 0.28 & 5.63 \\
\hline 17 & 4.09 & 24.2 & 0.039 & 16.91 & 2.63 & 30.25 & 0.33 & 5.45 \\
\hline 18 & 4.17 & 21.9 & 0.031 & 16.14 & 2.43 & 29.26 & 0.31 & 5.44 \\
\hline 19 & 4.18 & 25.2 & 0.033 & 16.56 & 2.59 & 30.40 & 0.32 & 5.45 \\
\hline 20 & 5.09 & 25.0 & 0.031 & 16.36 & 2.39 & 28.42 & 0.32 & 5.46 \\
\hline 21 & 5.10 & 23.0 & 0.028 & 13.31 & 1.43 & 20.89 & 0.26 & 5.44 \\
\hline 22 & 6.06 & 26.3 & 0.026 & 16.35 & 2.19 & 26.01 & 0.31 & 5.41 \\
\hline 23 & 6.07 & 34.1 & 0.028 & 13.76 & 2.00 & 28.20 & 0.27 & 5.55 \\
\hline 24 & 6.11 & 35.0 & 0.026 & 14.91 & 2.24 & 29.15 & 0.29 & 5.46 \\
\hline 25 & 6.12 & 36.9 & 0.023 & 15.19 & 2.12 & 27.13 & 0.29 & 5.47 \\
\hline 26 & 6.13 & 35.0 & 0.023 & 14.94 & 2.09 & 27.17 & 0.29 & 5.48 \\
\hline 27 & 6.15 & 35.8 & 0.023 & 13.77 & 1.82 & 25.69 & 0.27 & 5.53 \\
\hline 28 & 10.29 & 24.9 & 0.031 & 15.41 & 1.98 & 25.02 & 0.29 & 5.40 \\
\hline 29 & 10.30 & 23.2 & 0.031 & 12.34 & 1.41 & 22.19 & 0.24 & 5.39 \\
\hline 30 & 10.31 & 21.7 & 0.031 & 13.20 & 1.46 & 21.53 & 0.25 & 5.39 \\
\hline 31 & 11.01 & 20.1 & 0.028 & 14.46 & 1.43 & 19.22 & 0.28 & 5.43 \\
\hline 32 & 11.02 & 19.2 & 0.034 & 14.64 & 1.38 & 18.34 & 0.28 & 5.48 \\
\hline 33 & 11.22 & 15.2 & 0.029 & 13.39 & 1.15 & 16.67 & 0.25 & 5.27 \\
\hline
\end{tabular}




\begin{tabular}{|c|c|c|c|c|c|c|c|c|}
\hline 34 & 11.23 & 14.8 & 0.026 & 13.72 & 0.99 & 14.04 & 0.26 & 5.31 \\
\hline 35 & 11.24 & 18.0 & 0.028 & 12.17 & 1.04 & 16.58 & 0.23 & 5.29 \\
\hline 36 & 11.25 & 17.7 & 0.026 & 11.13 & 0.78 & 13.61 & 0.21 & 5.21 \\
\hline 37 & 11.26 & 17.17 & 0.029 & 12.27 & 1.07 & 16.94 & 0.23 & 5.20 \\
\hline 38 & 11.27 & 21.0 & 0.029 & 12.64 & 1.18 & 18.09 & 0.24 & 5.30 \\
\hline 39 & 11.28 & 18.8 & 0.029 & 11.79 & 0.96 & 15.77 & 0.22 & 5.33 \\
\hline 40 & 11.29 & 19.4 & 0.029 & 9.53 & 0.59 & 11.96 & 0.18 & 5.22 \\
\hline
\end{tabular}

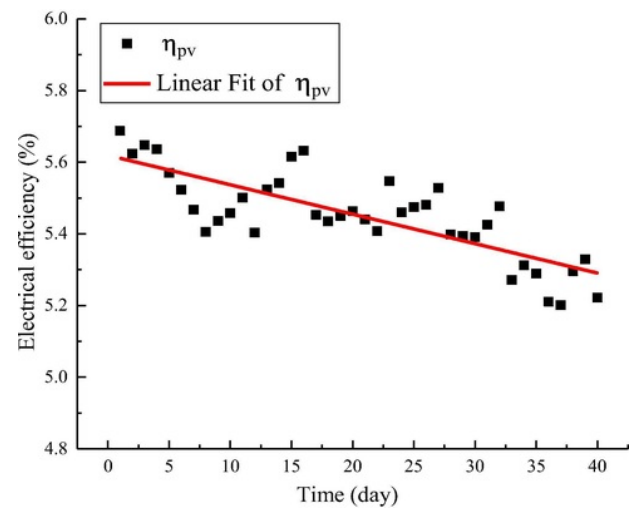

Fig. 12 Variations of the electrical efficiencies during long-term experiments.

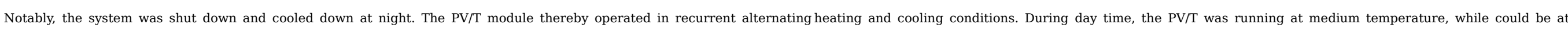

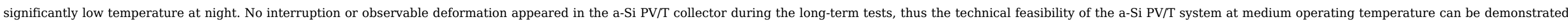
preliminarily.

\subsubsection{Experimental results at the operating temperature of $70^{\circ} \mathrm{C}$}

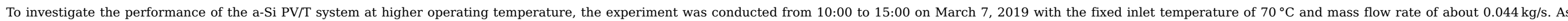

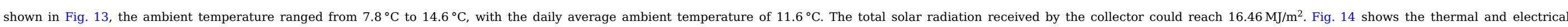

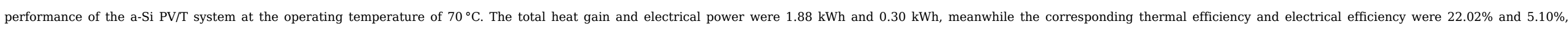
respectively. 


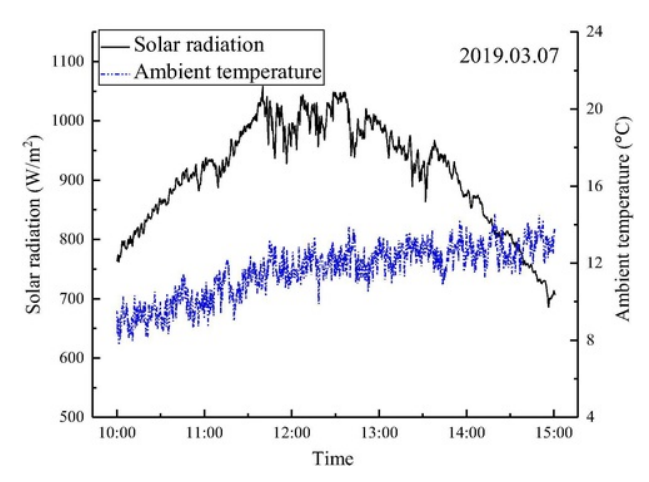

Fig. 13 Variations of ambient temperature and solar radiation on March 7, 2019

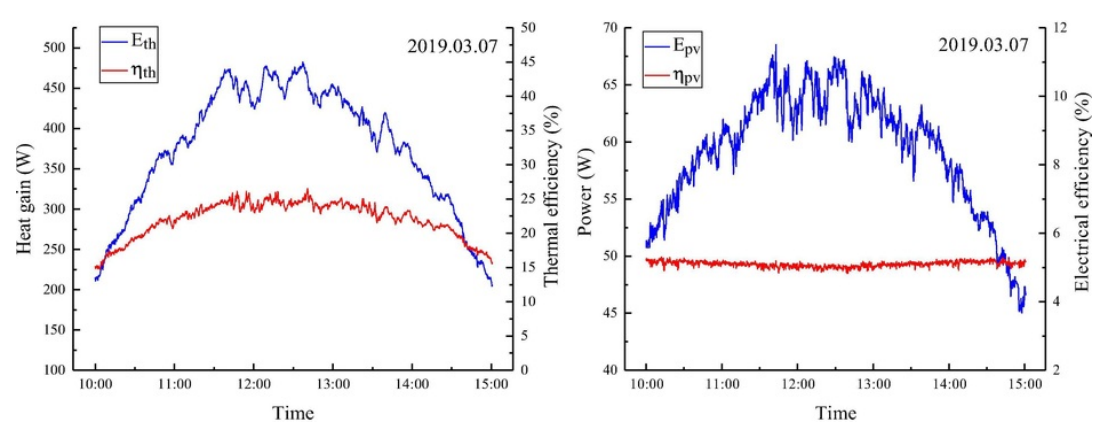

Fig. 14 Variations of thermal and electrical performance on March 7, 2019.

\subsubsection{Experimental results at the operating temperature of $80^{\circ} \mathrm{C}$}

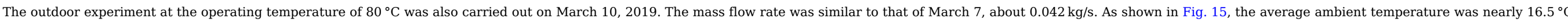

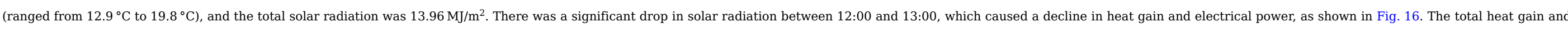

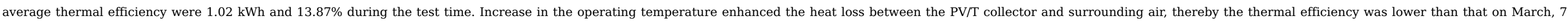
Besides, the total electrical power and average electrical efficiency were $0.24 \mathrm{kWh}$ and $4.81 \%$.

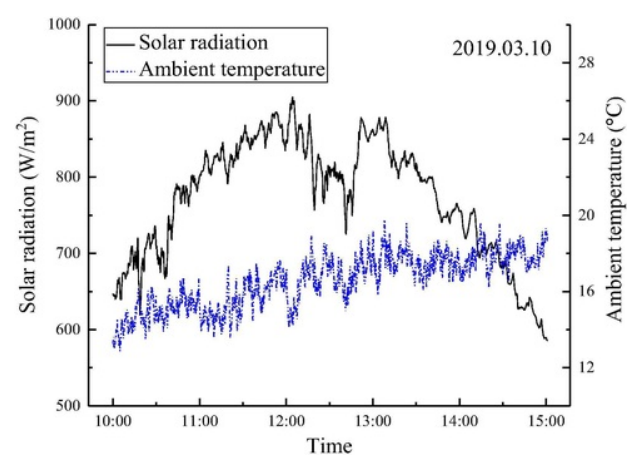

Fig. 15 Variations of ambient temperature and solar radiation on March 10, 2019. 


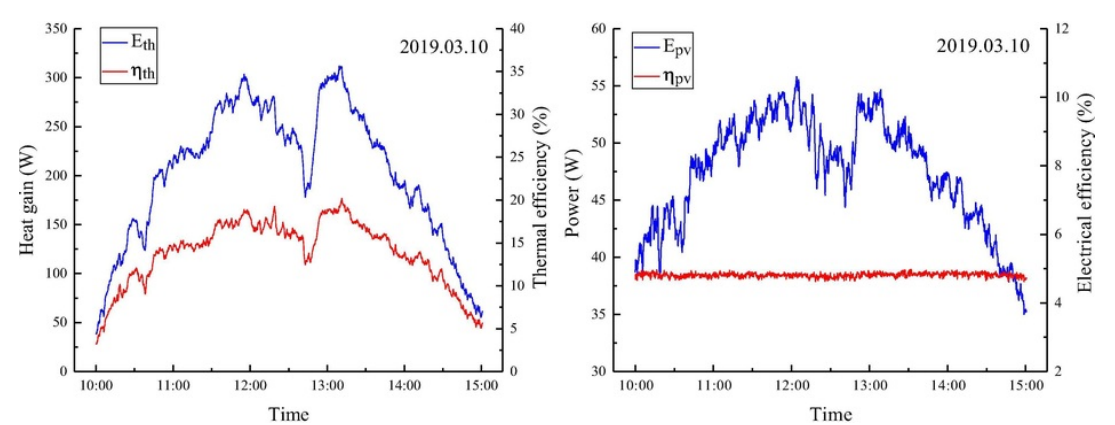

Fig. 16 Variations of thermal and electrical performance on March 10, 2019.

\subsubsection{Regression formulation of thermal efficiency}

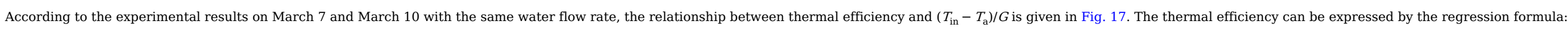
$\eta_{\text {th }}=0.4936-4.241 \frac{T_{\text {in }}-T_{a}}{G}$

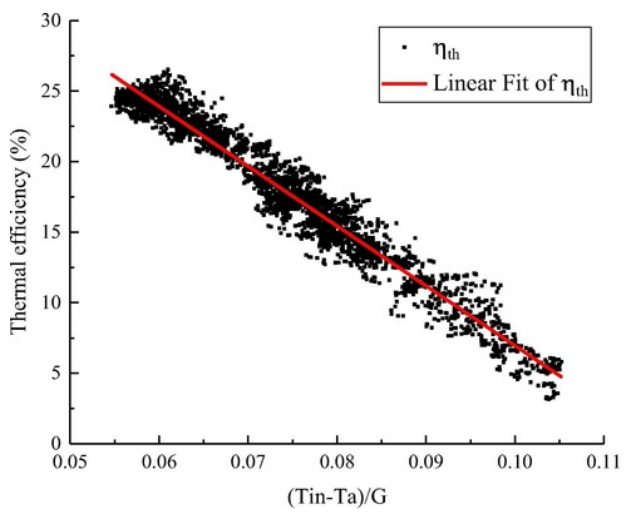

Fig. 17 Plot of thermal efficiency of a-Si PV/T collector.

As presented in the regression line, the intercept thermal efficiency is $49.36 \%$. With the increase of $\left(T_{\text {in }}-T_{\mathrm{a}}\right) / G$, the thermal efficiency decreased gradually with a slope of -4.241 .

\subsubsection{Uncertainly analysis of experiment}

The uncertainties of the measurements need to be analyzed due to the possible measurement errors of measuring instruments. The calculation of uncertainty is given by

$\Delta y=\left[\left(\frac{\partial f}{\partial x_{1}}\right)^{2}\left(\Delta x_{1}\right)^{2}+\left(\frac{\partial f}{\partial x_{2}}\right)^{2}\left(\Delta x_{2}\right)^{2}+\cdots+\left(\frac{\partial f}{\partial x_{n}}\right)^{2}\left(\Delta x_{n}\right)^{2}\right]^{\frac{1}{2}}$

where $f$ is the function of indirect measurement that requires an uncertainty analysis; $x$ is one of the variables of the function; $\Delta x$ is the absolute error of the variable.

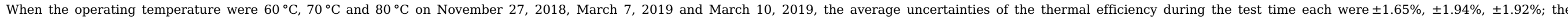
uncertainties of the electrical efficiency were $\pm 0.11 \%, \pm 0.10 \%$ and $\pm 0.10 \%$. Therefore, the measuring instruments could ensure good accuracy of the experimental results.

\subsection{Numerical analysis}

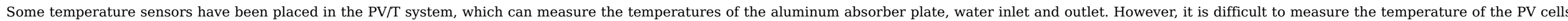




\subsubsection{Inside views of temperature distribution}

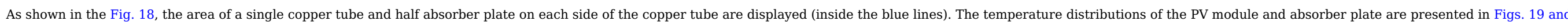

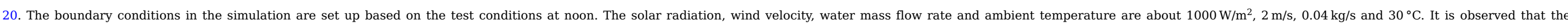

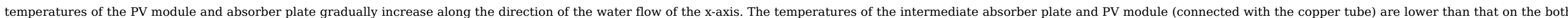

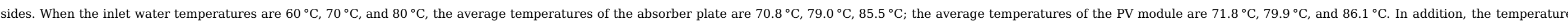

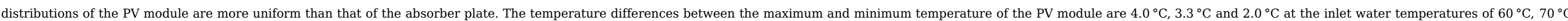

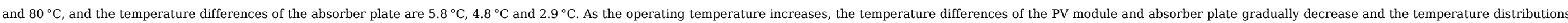
become more uniform.

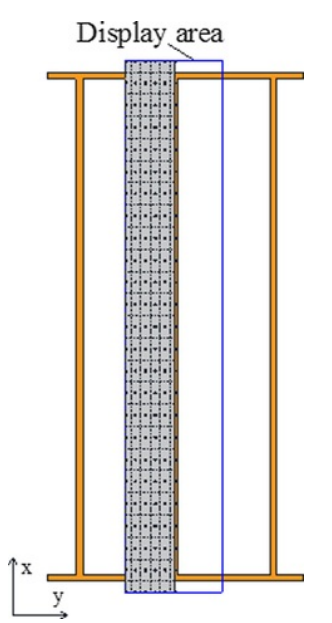

Fig.18 Display area of the PV module and absorber plate.

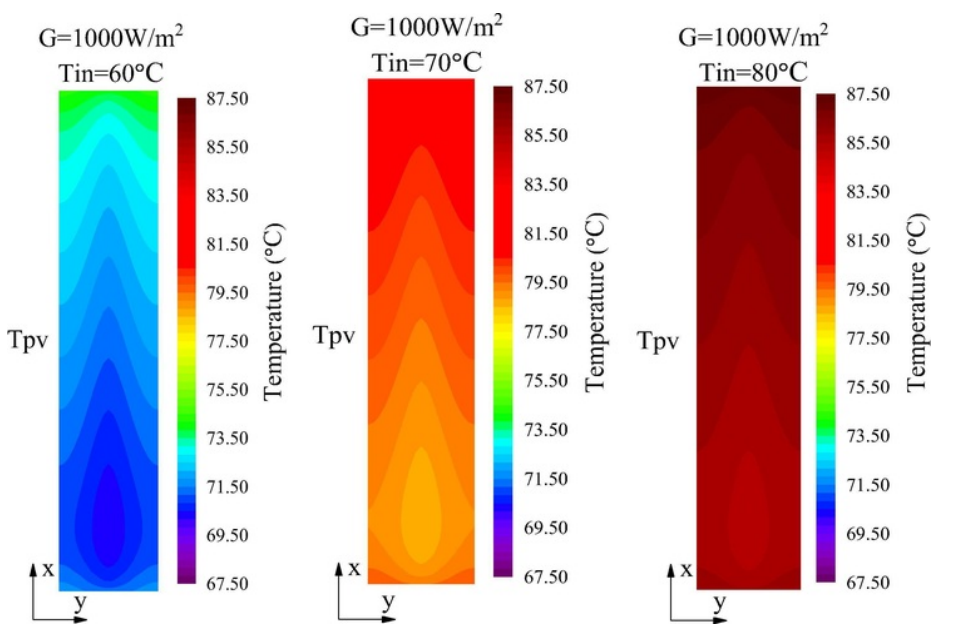




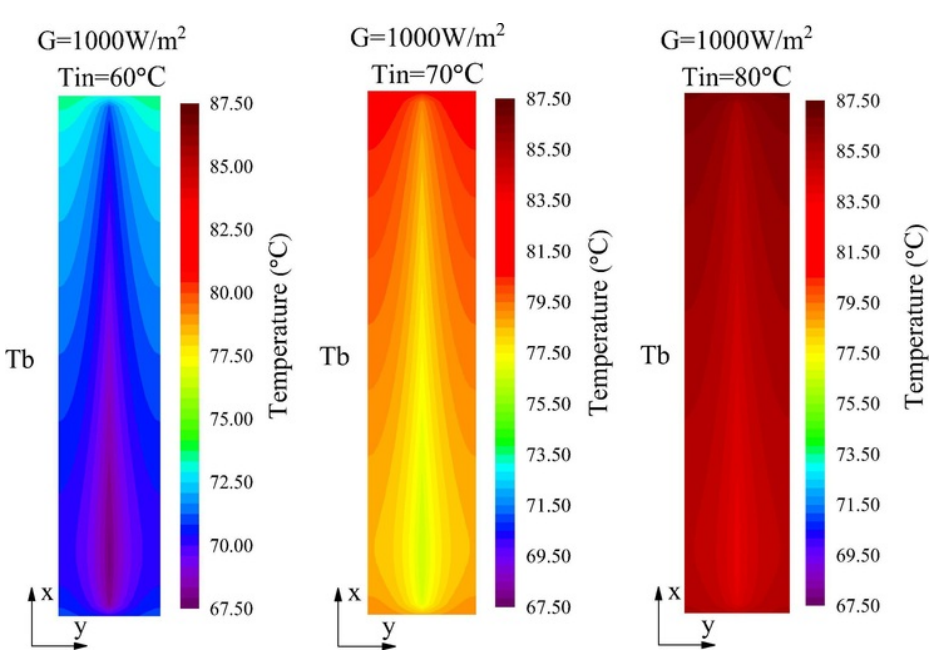

Fig. 20 Temperature distributions of the absorber plate at different inlet temperatures.

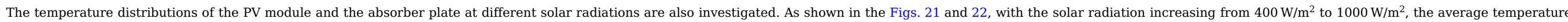

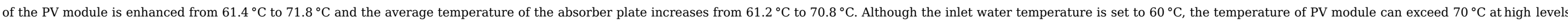
of solar radiation, even as high as $74.3^{\circ} \mathrm{C}$. The feasibility of the a-Si PV/T system at medium operating temperature can be further demonstrated.

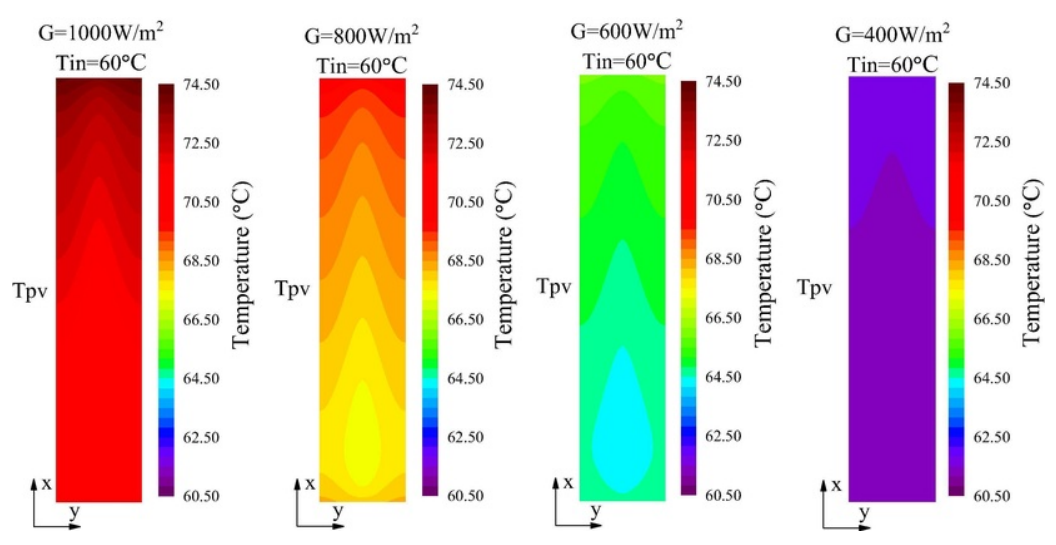

Fig. 21 Temperature distributions of the PV module at different solar radiations. 


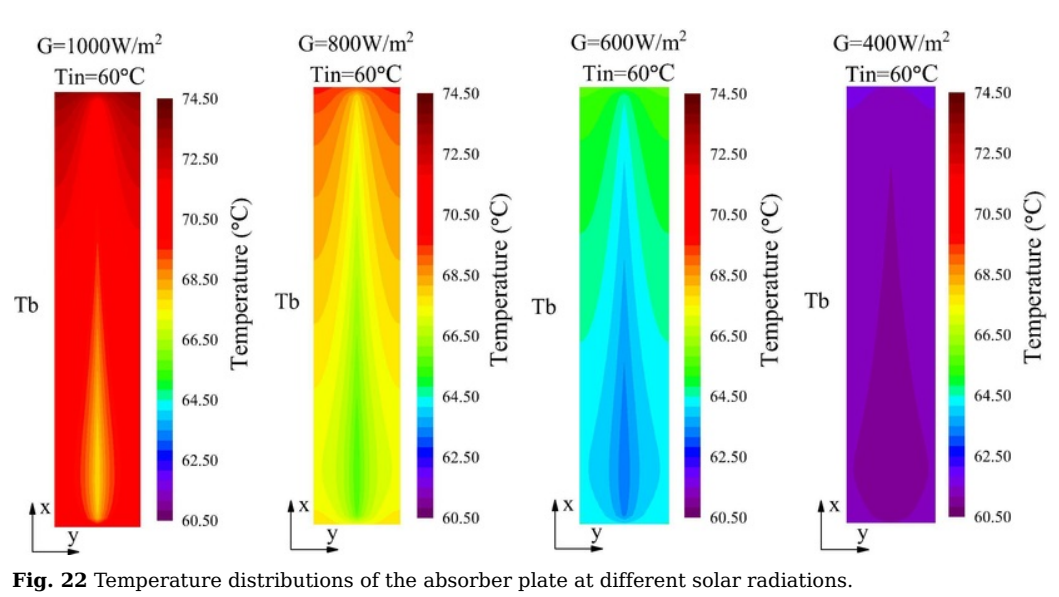

Fig. 22 Temperature distributions of the absorber plate at different solar radiation

\subsubsection{Experimental validation}

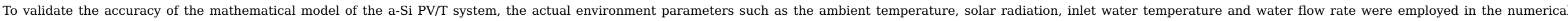

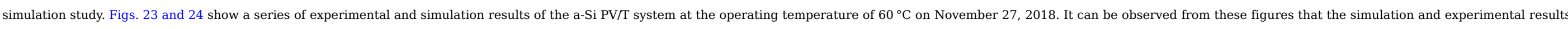

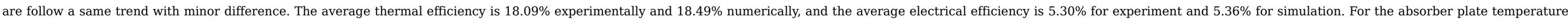

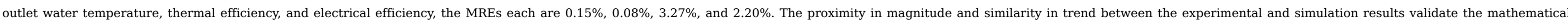
model of the a-Si PV/T system.

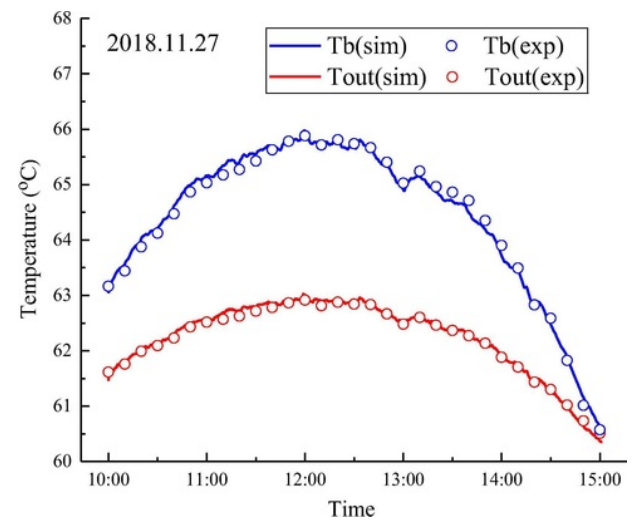

Fig. 23 Experimental and simulation results of absorber plate and outlet temperature at the operating temperature of $60^{\circ} \mathrm{C}$. 

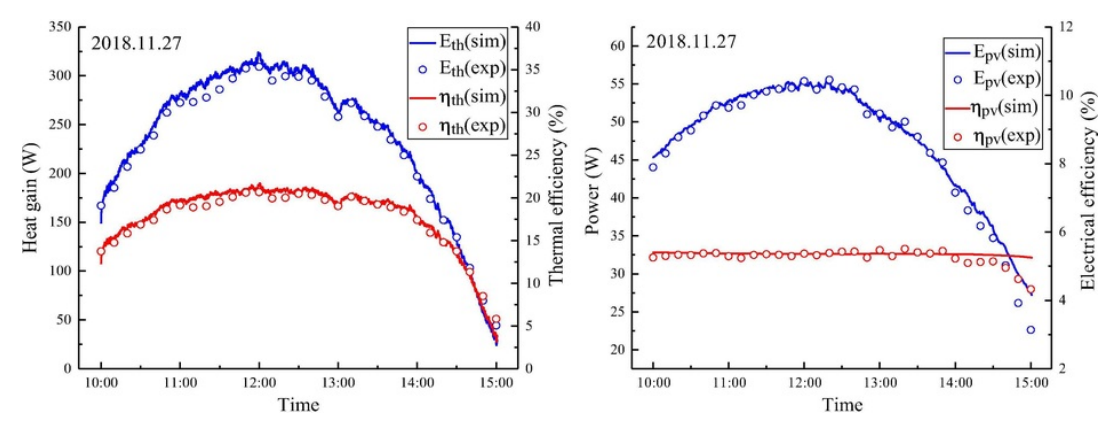

Fig. 24 Experimental and simulation results of thermal and electrical performance at the operating temperature of $60^{\circ} \mathrm{C}$.

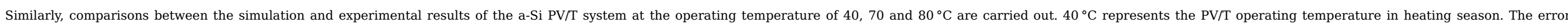

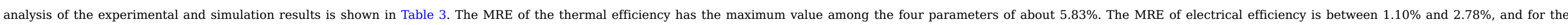

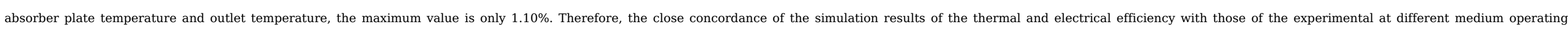
temperatures confirms the effectiveness of the proposed mathematic model.

Table 3 MREs between the simulation and the experimental results at different operating temperatures.

$$
T_{\text {in }}\left({ }^{\circ} \mathrm{C}\right)
$$

$\eta_{\text {th }}$

\begin{tabular}{|l|l|}
\hline 5.83 & 2.78 \\
\hline 3.27 & 2.20 \\
\hline 2.54 & 1.10 \\
\hline 4.99 & 1.96 \\
\hline
\end{tabular}

MRE (\%)

$\eta_{\mathrm{pv}}$

\begin{tabular}{|l|l|}
\hline 1.10 & 0.34 \\
\hline 0.15 & 0.08 \\
\hline 0.31 & 0.11 \\
\hline 0.21 & 0.07 \\
\hline
\end{tabular}

\subsubsection{Grid independence test}

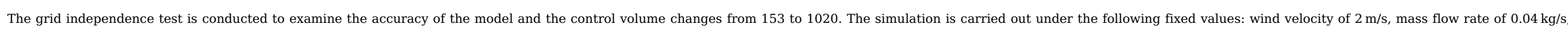

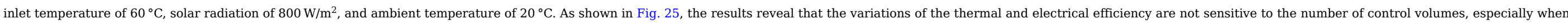

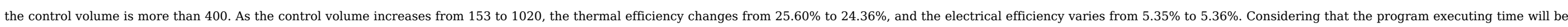
significantly prolonged with increasing control volumes, 561 control volumes are applied in this study.

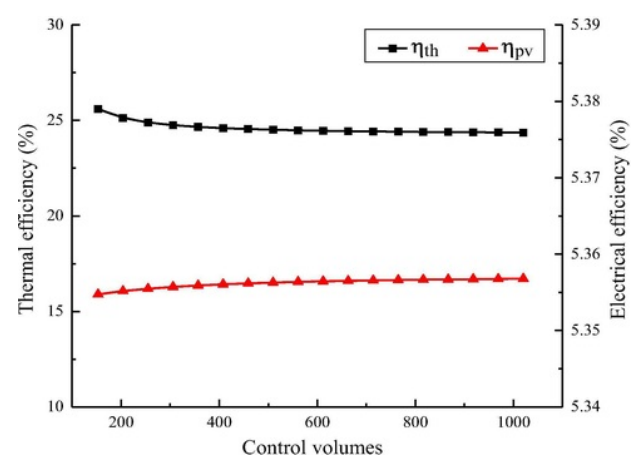




\subsection{Performance prediction}

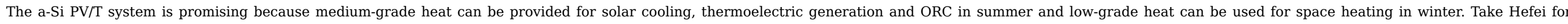

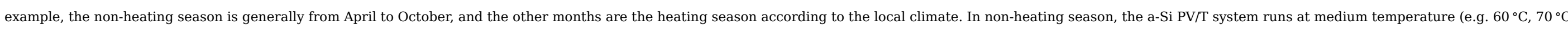
and $80^{\circ} \mathrm{C}$ ). In heating season, the operating temperature is $40^{\circ} \mathrm{C}$, and the hot water can be used for heating homes and offices.

\subsubsection{Performance in the non-heating season}

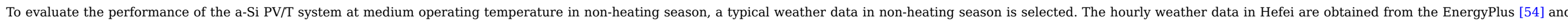

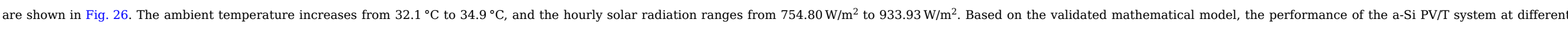

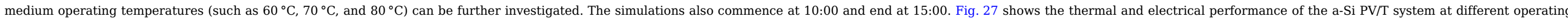

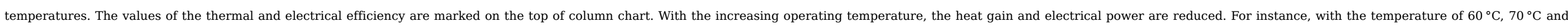
$80^{\circ} \mathrm{C}$, the hourly heat gains between 12:00 and 13:00 are $584.50 \mathrm{~W}, 465.87 \mathrm{~W}$ and $343.42 \mathrm{~W}$; the electrical powers are $62.68 \mathrm{~W}, 60.27 \mathrm{~W}$ and $57.87 \mathrm{~W}$, respectively.

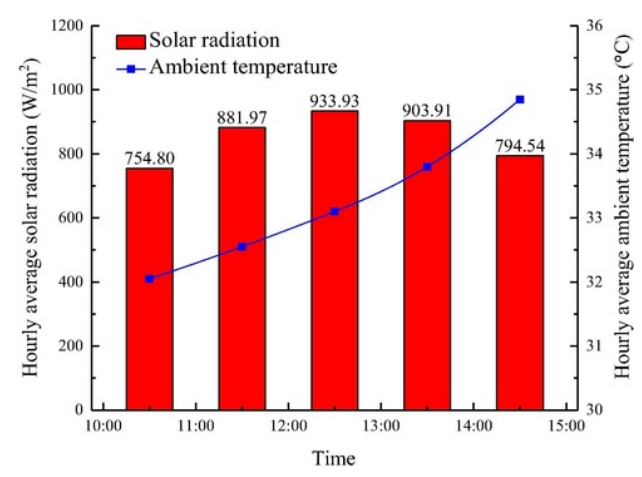

Fig. 26 Hourly solar radiation and ambient temperature.
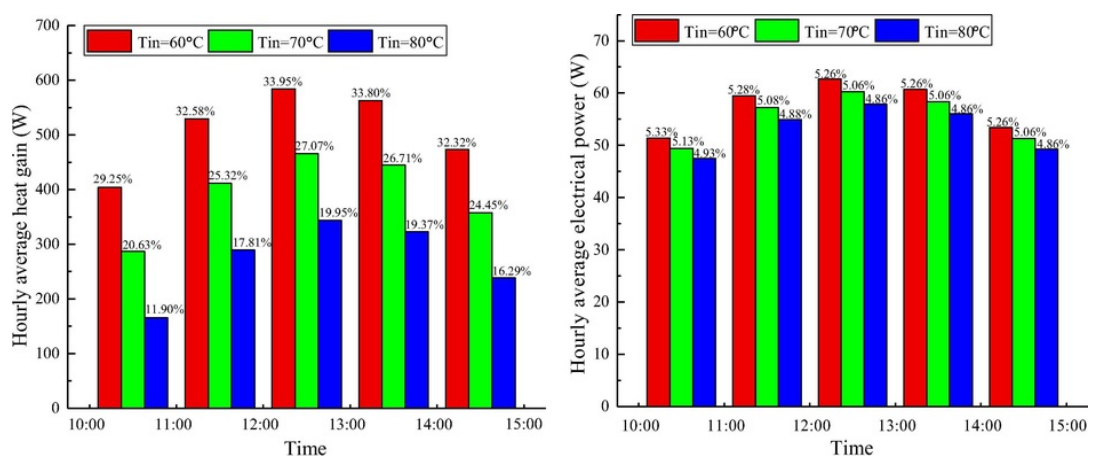

Fig. 27 Hourly thermal and electrical performance of the a-Si PV/T system at different operating temperatures.

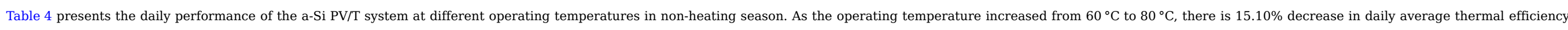
but only $0.4 \%$ decrease in the electrical efficiency.

Table 4 Daily performance of the a-Si PV/T system at different operating temperatures. 


\begin{tabular}{|c|c|c|c|c|c|c|}
\hline$T_{\text {in }}\left({ }^{\circ} \mathrm{C}\right)$ & $\overline{T_{a}}(\circ C)$ & $\mathrm{H}\left(\mathrm{MJ} / \mathrm{m}^{2}\right)$ & $\mathrm{Q}_{\mathrm{th}}(\mathrm{kWh})$ & $\eta_{\text {th,a }}(\%)$ & $\mathrm{Q}_{\mathrm{pv}}(\mathrm{kWh})$ & $\eta_{\mathrm{pv}, \mathrm{a}}(\%)$ \\
\hline 60 & 33.3 & 15.37 & 2.55 & $32.29 \%$ & 0.29 & 5.28 \\
\hline 70 & & & 1.97 & $24.87 \%$ & 0.28 & 5.08 \\
\hline 80 & & & 1.36 & $17.19 \%$ & 0.27 & 4.88 \\
\hline
\end{tabular}

\subsubsection{Annual performance}

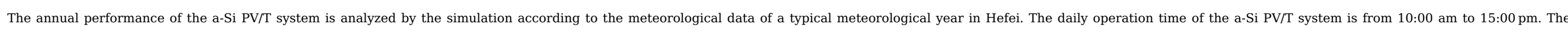

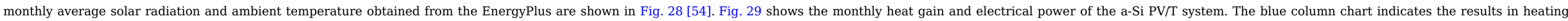

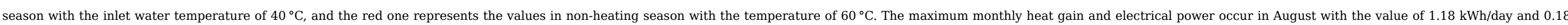

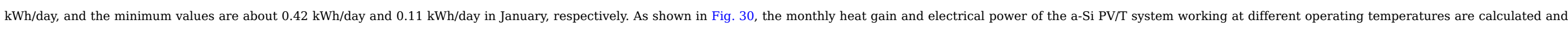

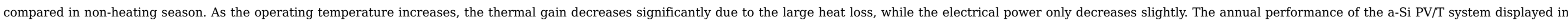
Table 5 is calculated according to the results shown in Figs. 29 and 30.

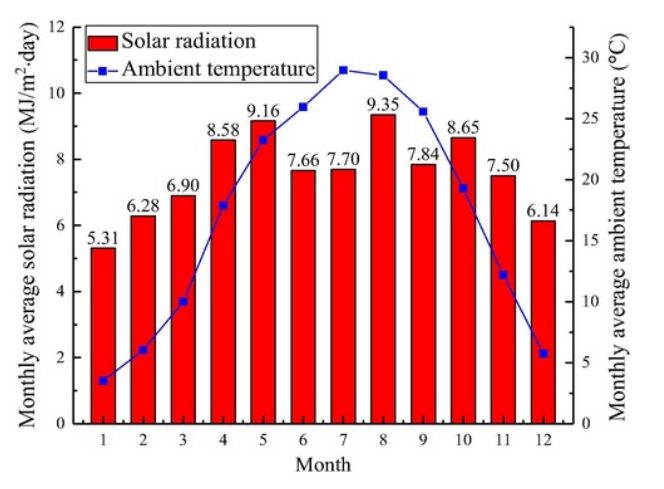

Fig. 28 Monthly average solar radiation and ambient temperature.

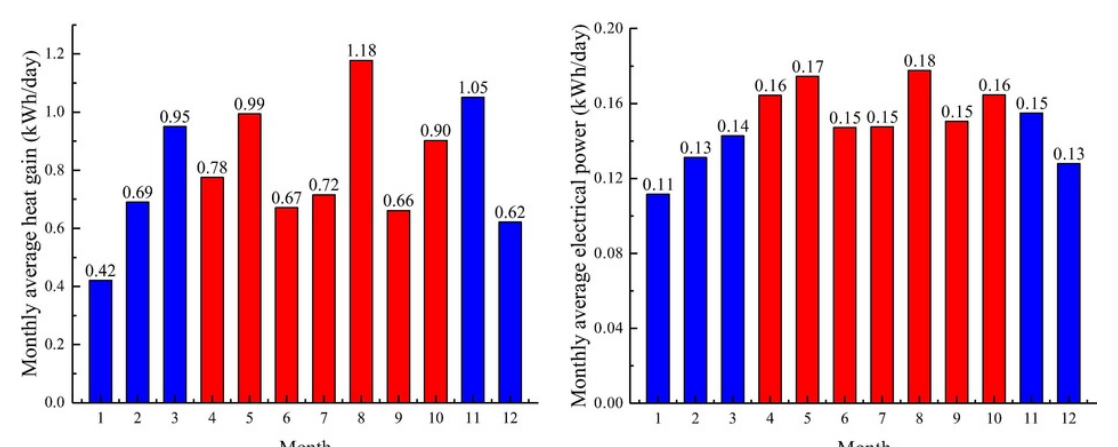

Month

Month

Fig. 29 Monthly heat gain and electrical power of the a-Si PV/T system. 


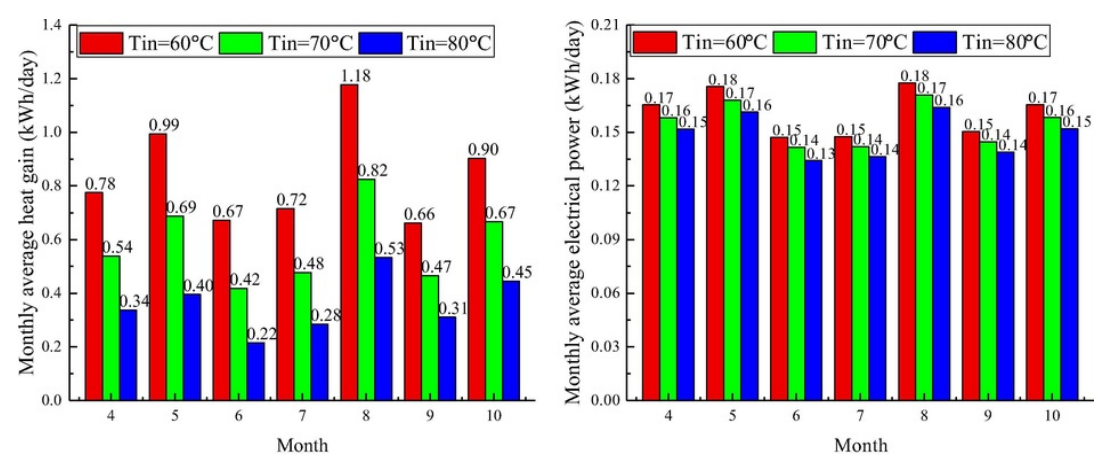

Fig. 30 Monthly heat gain and electrical power in non-heating season at different operating temperatures.

Table 5 Annual performance of the a-Si PV/T system.

\begin{tabular}{|c|c|c|c|c|}
\hline & Temperature $\left({ }^{\circ} \mathrm{C}\right)$ & $H\left(\mathrm{MJ} / \mathrm{m}^{2}\right)$ & $Q_{\mathrm{w}}(\mathrm{kWh})$ & $E_{\mathrm{pv}}(\mathrm{kWh})$ \\
\hline Heating season & 40 & 969.79 & 112.62 & 20.17 \\
\hline \multirow[t]{3}{*}{ Non-heating season } & 60 & \multirow[t]{3}{*}{1802.98} & 180.75 & 34.45 \\
\hline & 70 & & 124.96 & 33.14 \\
\hline & 80 & & 49.53 & 31.83 \\
\hline
\end{tabular}

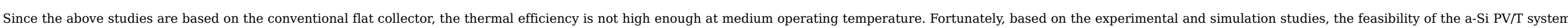

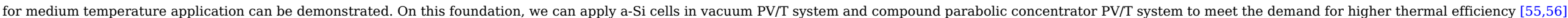

\section{Conclusion}

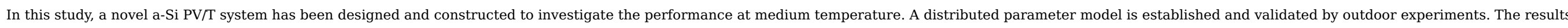
are summarized as follows.

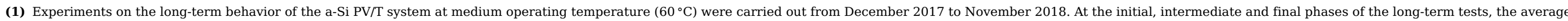

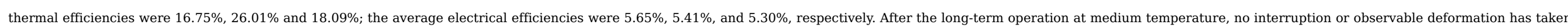
place in the a-Si PV/T system.

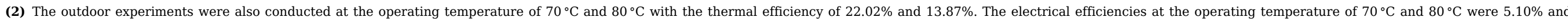
$4.81 \%$.

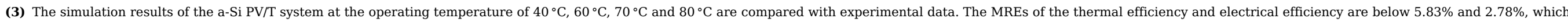
can prove the effectiveness of the mathematical model in predicting the performance of the a-Si PV/T system.

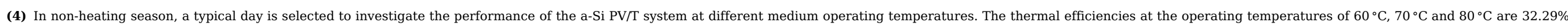
$24.87 \%$ and $17.19 \%$; the electrical efficiency are $5.28 \%, 5.08 \%$ and $4.88 \%$, respectively.

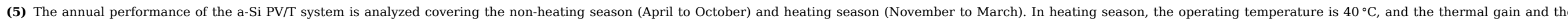
electrical power are $112.62 \mathrm{kWh}$ and $20.17 \mathrm{kWh}$. In non-heating season, the thermal gain and the electrical power are $180.75 \mathrm{kWh}$ and $34.45 \mathrm{kWh}$ with the operating temperature of $60{ }^{\circ} \mathrm{C}$.

(6) Based on the experimental and simulated results, the technical and thermodynamic feasibility of the a-Si PV/T system for medium temperature application is demonstrated. 


\section{Acknowledgments}

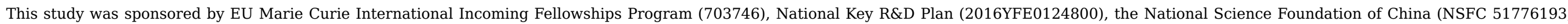
and 51761145109), and Bureau of International Cooperation, Chinese Academy of Sciences (211134KYSB20160005).

\section{References}

[1] T.T. Chow, A review on photovoltaic/thermal hybrid solar technology, Appl Energy 87, 2010, 365-379.

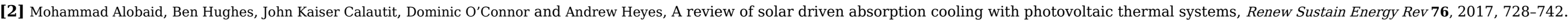

[3] Wei He, Gan Zhang, Xingxing Zhang, Jie Ji, Guiqiang Li and Xudong Zhao, Recent development and application of thermoelectric generator and cooler, Appl Energy 143 (1), 2015, 1-25.

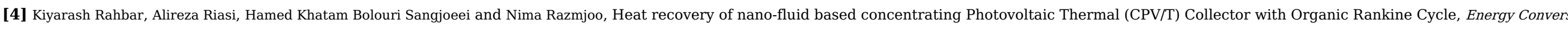
Manag 179 (1), 2019, 373-399.

[5] G. Vokas, N. Christandonis and F. Skittides, Hybrid photovoltaic-thermal systems for domestic heating and cooling-a theoretical approach, Sol Energy 80 (5), 2006 , 607-615.

[6] G. Mittelman, A. Kribus and A. Dayan, Solar cooling with concentrating photovoltaic/thermal (CPVT) systems, Energy Convers Manag 48 (9), $2007,2481-2490$.

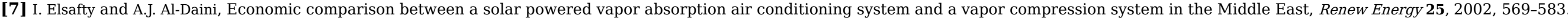

[8] E.A. Chávez-Urbiola, Yu.V. Vorobiev and L.P. Bulat, Solar hybrid systems with thermoelectric generators, Sol Energy 86, 2012, 369-378.

[9] A. Rezania and L.A. Rosendahl, Feasibility and parametric evaluation of hybrid concentrated photovoltaic-thermoelectric system, Appl Energy 187, 2017, 380-389.

[10] Jing Li, Gang Pei, Yunzhu Li and Jie Ji, Novel design and simulation of a hybrid solar electricity system with organic Rankine cycle and PV cells, Int. J. Low-Carbon Tech. 4 (5), 2010, 223-230.

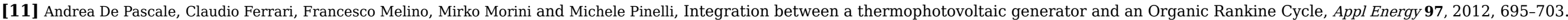

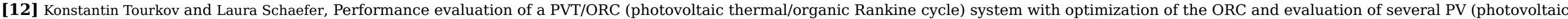
materials, Energy 82, 2015, 839-849.

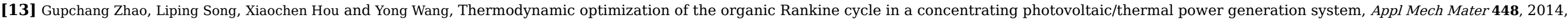
$1514-1518$.

[14] Can Coskun, Ugurtan Toygar, Ozgur Sarpdag and Zuhal Oktay, Sensitivity analysis of implicit correlations for photovoltaic module temperature: a review, J Clean Prod 164, 2017, 1474-1485.

[15] E. Radziemska, The effect of temperature on the power drop in crystalline silicon solar cells, Renew Energy 28, 2003, 1-12.

[16] W.C. O'Mara, R.B. Herring and I.P. Hunt, Handbook of semiconductor silicon technology, 1990, Noyes Publications; Park Ridge, New Jersey, ISBN 0-8155-1237-6.

[17] Wim G.J. van Helden, Ronald J.Ch. van Zolingen and Herbert A. Zondag, PV thermal systems: PV panels supplying renewable electricity and heat, Prog Photovolt: Res Appl 12, 2004, 415-426.

[18] Jean Zaraket, Michel Aillerie and Chafic Salame, Capacitance evolution of PV solar modules under thermal stress, Energy Proc 119, 2017, 702-708.

[19] M. Shihabudheen and P. Arun, Performance evaluation of a hybrid photovoltaic-thermal water heating system, Int J Green Energy 11, 2014, 969-986.

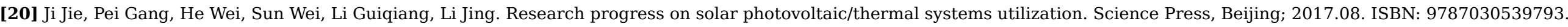

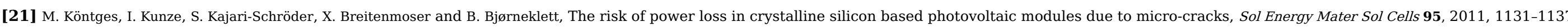

[22] M. Wang, J. Peng, N. Li, L. Lu and H. Yang, Experimental study on thermal performance of semi-transparent PV window in winter in Hong Kong, Energy Proc 105, 2017, 864-868. 
[23] Jinqing Peng, Lin Lu and Hongxing Yang, An experimental study of the thermal performance of a novel photovoltaic double-skin facade in Hong Kong, Sol Energy 97, 2013, 293-304.

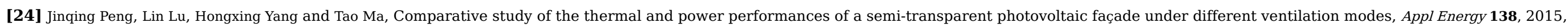
$572-583$.

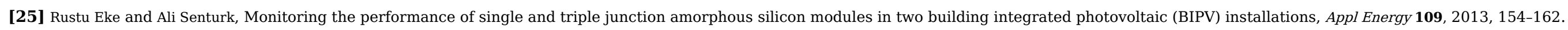

[26] W. Zhang, B. Hao and N. Li, Experiment and simulation study on the amorphous silicon photovoltaic walls, Int J Photoenergy $2014,2014,643637$.

[27] Ershuai Yin, Qiang Li and Yimin Xuan, Thermal resistance analysis and optimization of photovoltaic thermoelectric hybrid system, Energy Convers Manage 143, 2017 , 188-202.

[28] R. Bjørk and K.K. Nielsen, The performance of a combined solar photovoltaic (PV) and thermoelectric generator (TEG) system, Sol Energy 120, 2015, 187-194.

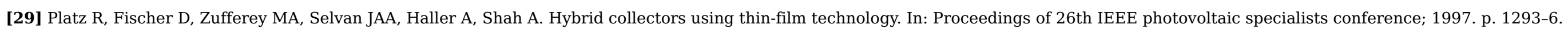

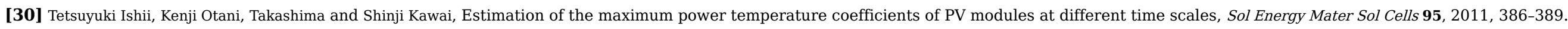

[31] G. Makrides, B. Zinsser, A. Phinikarides, M. Schubert and G.E. Georghiou, Temperature and thermal annealing effects on different photovoltaic technologies, Renew Energy 43, 2012 , 407-417.

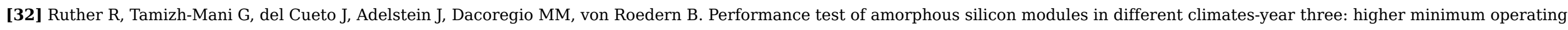
temperatures lead to higher performance levels. In: Proceedings of 31th IEEE photovoltaic specialists conference; 2005. p. 1635-8.

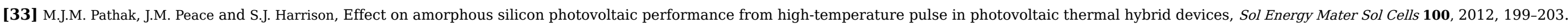

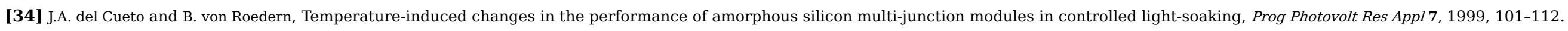

[35] J. Yang, A. Banerjee and S. Guha, Triple-junction amorphous silicon alloy solar cell with 14.6\% initial and 13.0\% stable conversion efficiencies, Appl Phys Lett 70, 1997, $2975-2977$.

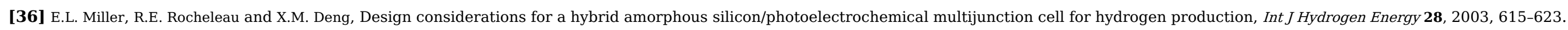

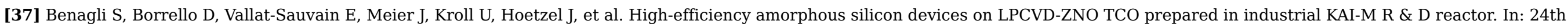
European photovoltaic solar energy conference, Hamburg; September 2009.

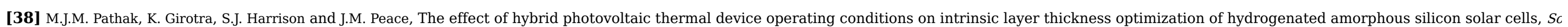
Energy 86, 2012, 2673-2677.

[39] J. Rozario and J.M. Pearce, Optimization of annealing cycles for electric output in outdoor conditions for amorphous silicon photovoltaic-thermal systems, Appl Energy 148, 2015, 134-414.

[40] S.A. Kalogirou and Y. Tripanagnostopoulos, Hybrid PV/T solar systems for domestic hot water and electrical production, Energy Convers Manage 47, $2006,3368-3382$.

[41] Kanchan Vats and G.N. Tiwari, Energy and exergy analysis of a building integrated semitransparent photovoltaic thermal (BISPVT) system, Appl Energy 96, 2012 , 409-416.

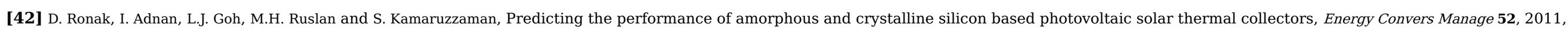
1741-1747.

[43] T. Nualboonrueng, P. Tuenpusa, Y. Ueda and A. Akisawa, Field experiments of PV-Thermal collectors for residential application in Bangkok, Energies 5, 2012, $1229-1244$.

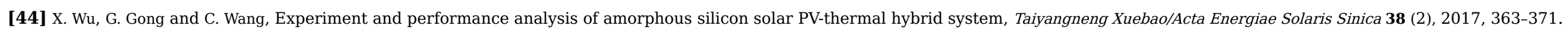

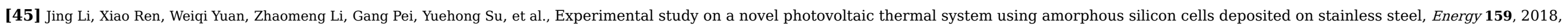
$786-798$. 
[46] Runsheng Tang and Tong Wu, Optimal tilt-angles for solar collectors used in China, Appl Energy 79, 2004, 239-248.

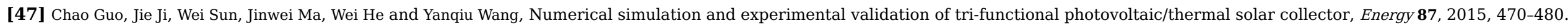

[48] J.A. Duffie and W.A. Beckman, Solar engineering of thermal processes (4th ed.), 2013, John Wiley \& Sons Inc.

[49] T.L. Bergman, F.P. Incropera, D.P. DeWitt and A.S. Lavine, Fundamentals of heat and mass transfer, 2011, John Wiley \& Sons.

[50] ANSI/ASHRAE 93-2010 Methods of testing to determine the thermal performance of solar collectors. New York: ASHRAE; 2010.

[51] D.L. Staebler and C.R. Wronski, Reversible conductivity changes in discharge-produced amorphous Si, Appl Phys Lett 31, 1977, $292-294$.

[52] M. Nikolaeva, R.P. Kenny, E. Dunlop and M. Pravettoni, Seasonal variations on energy yield of a-Si, hybrid, and crystalline Si PV modules, Prog Photovolt Res Appl 18, 2010, 311-320.

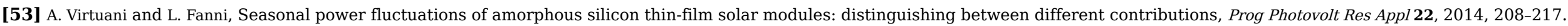

[54] < https://www.energyplus.net/weather-location/asia_wmo_region_2/CHN//CHN_Anhui.Hefei.583210_CSWD>.

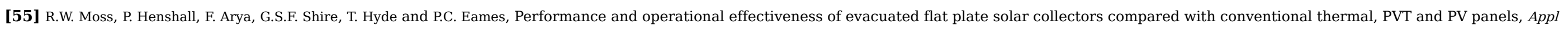
Energy 216, 2018, 588-601.

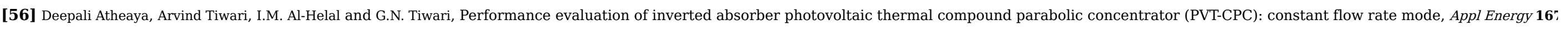
2016, 70-79.

\section{Footnotes}

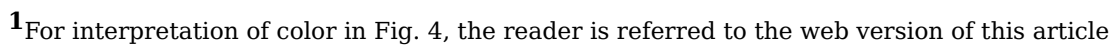

\section{Highlights}

- Design and construction of a novel standard sized a-Si PV/T system are introduced.

- Long-term experimental results of the system at medium temperature are presented.

- Distributed parameter model is established and validated by experiments.

- An insight to heat transfer and power generation is provided.

- The technical and thermodynamic feasibility at medium temperature is demonstrated.

\section{Queries and Answers}

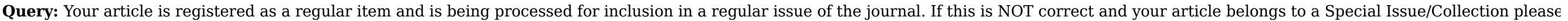
contact J.Shanmugam@elsevier.com immediately prior to returning your corrections.

Answer: Yes

Query: The author names have been tagged as given names and surnames (surnames are highlighted in teal color). Please confirm if they have been identified correctly.

Answer: Yes

Query: Please note that Fig. 4 will appear in B/W in print and color in the web version. Based on this, please approve the footnote 1 which explains this 


\section{Answer: I understand.}

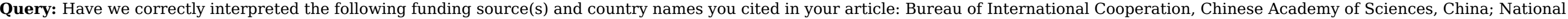
Science Foundation of China, China; Marie Curie, United Kingdom; ? /

Answer: Yes 